This dissertation has been

microfilmed exactly as received

BRUCE, William Alvin, 1941-

THE PERCEPTION OF INFRARED RADIATION BY THE SPINY

RAT MITE LAELAPS ECHIDNINA (ACARI: LAELAPIDAE).

The Ohio State University, Ph.D., 1969

Entomology

University Microfilms, Inc., Ann Arbor, Michigan 


\section{THE PERCEPTION OF INFRARED RADIATION BY THE \\ SPINY RAT MITE LAELAPS ECHIDNINA \\ (ACARI: LAELAPIDAE)}

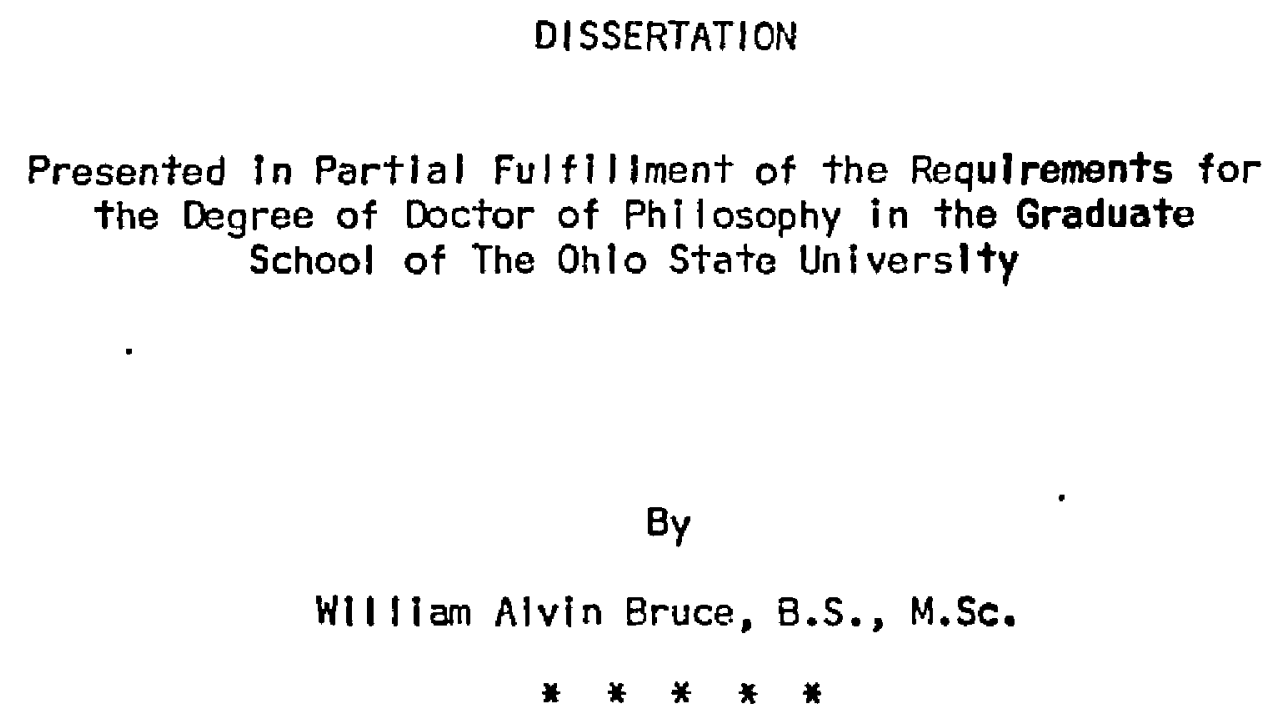

The Ohio State University

1969

Approved by

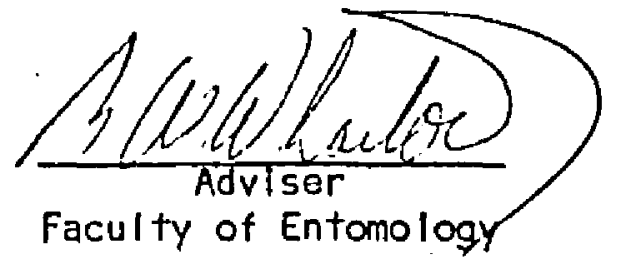




\section{ACKNOWLEDGMENTS}

I wish to express my Indebtedness and thanks to Will lam H. Peake, Edward K. Damon, and the Electroscience Laboratory for their unselfish cooperation and inferest and for providing the $\mathrm{CO}_{2}$ gas laser, the Perkin-Elmer monochromator, and necessary laboratory facllities.

Sincere appreciation is expressed to my adviser, George W. Wharton, for his suggestions, constructive criticlsms, and patience throughout the course of this study, and to Donald E. Johnston for constant inspiration and interest.

Valuable assistance was rendered by the following people: John H. McCoy gave technical instruction in the use of the laser and monochromator; W. Curt Lane provided technical assistance in scanning electron microscopy; Kay Lindsay aided in the preparation of electron micrographs; and my wife, Susan, typed the inltial manuscript and provided constant encouragement during this investigation.

An expression of gratitude is extended to those faculty members and graduate students at The Ohio State University who have helped to provide the creative and stimulating environment necessary for research and study.

Acknowledgment is made to the Acarology Laboratory, The Ohlo State University, and to the National Institute of Health for laboratory faclilitles and financlal support $\mathrm{CNIH}$ Predoctoral Tralneeshlp 5 TOl A1002(6-08) during the period of study. 


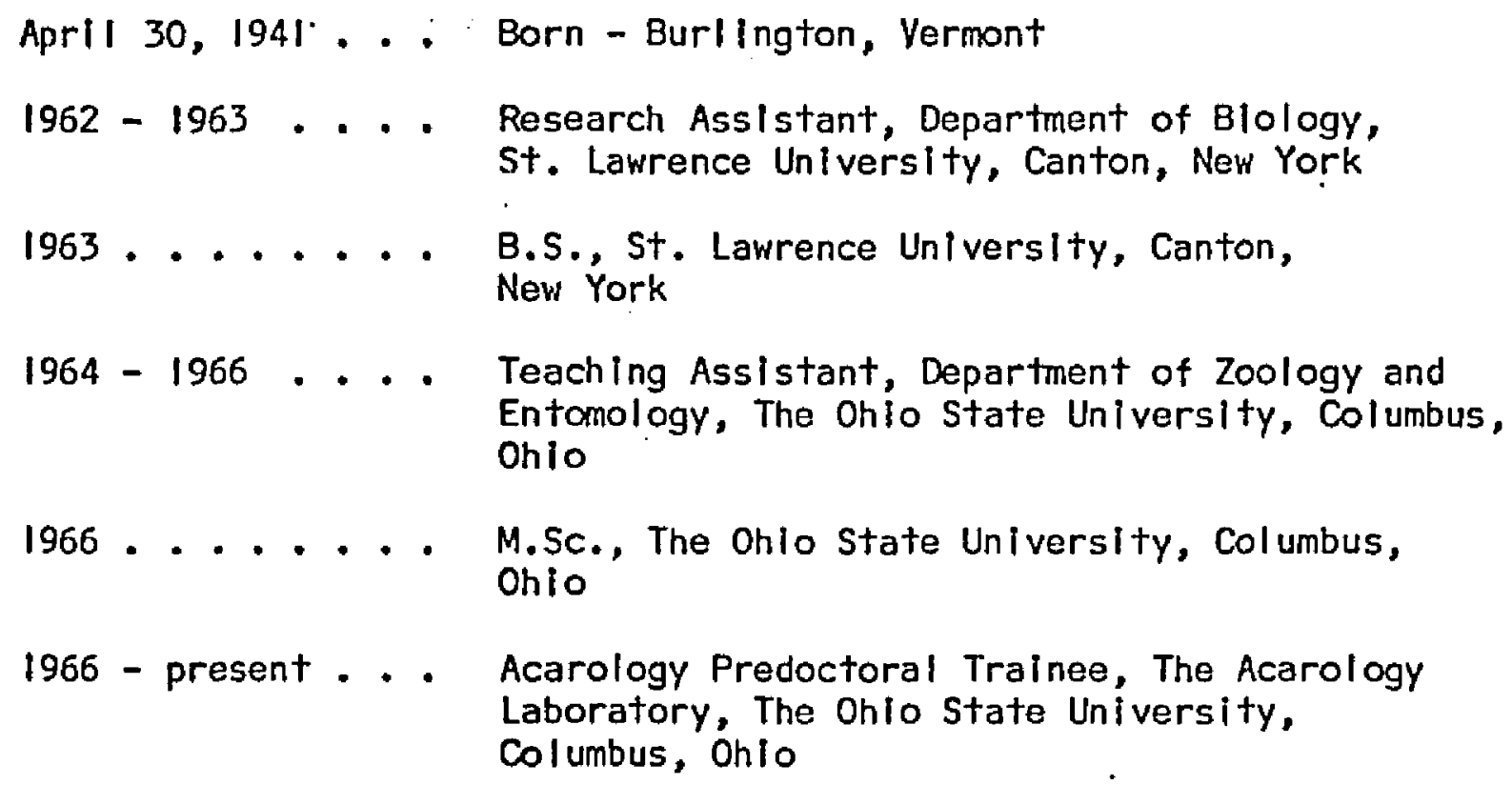

\section{PUBLICATIONS}

Johnston, D.E. and W.A. Bruce, 1965.

Tyrophagus neiswanderi a new acarid mlte of agricultural importance.

Ohio AgricuTfural Research and Development Center Research

. Bulletin $977.17 \mathrm{p}$.

Bruce, W.A. and D.E. Johnston. 1969.

A redescription of Pteronyssoides tyrrelli (Canestrini, 1899),

a feather mite from the tree swallow (Acari - Acarlformes). Acarologia 11(1):104-120.

\section{FIELDS OF STUDY}

\section{Major Field: Entomology}

Area of Specialization: Acarology. Professor G. W. Wharton 


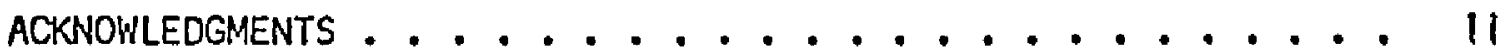

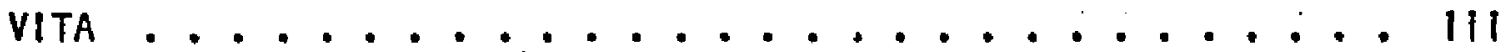

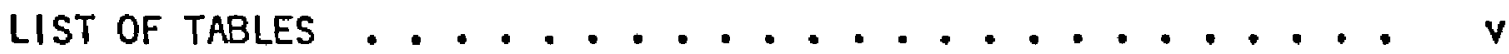

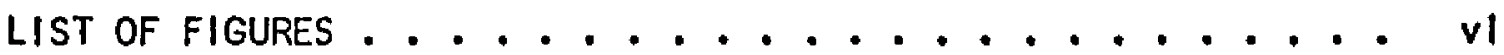

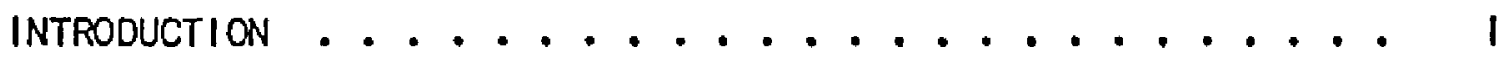

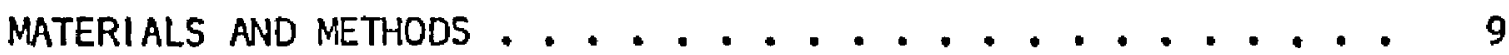
General Procedures Tarsus 1

Electron Microscopy

Radiation Sources

RESULTS

Electron Microscopy

Test Intensity

Wavelength Discrimination

Setal Measurements Coherent Radiation Receptor Location

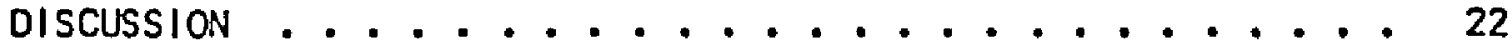

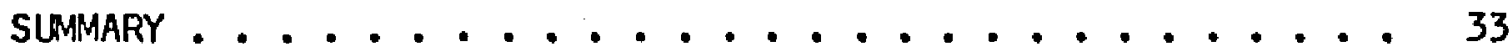

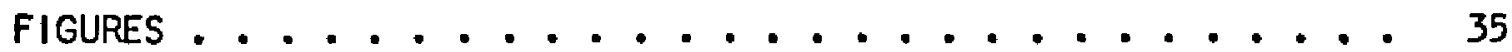

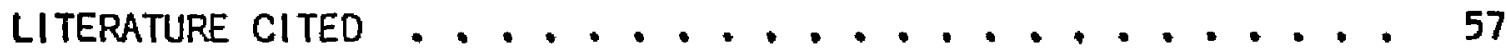




\section{LIST OF TABLES}

Table

Page

1 Determination of Test Intensity......... 17

2 Base Diameters of Hollow Setae on Tarsus 1..... 19

3 Length of Hollow Setae on Tarsus 1......... 20

4 Wavelengths at $D_{\max } \ldots \ldots 27$ 


\section{LIST OF FIGURES}

Figure

1 Laelaps echldnina Berlese; adult female; ventral aspect - 36

2 Perkin-Elmer Monochromator; source and fore prlsm components .................... 38

3 Camera shutter, exit slit, and test chamber; viewed from above ................. 38

4 Test chamber; observation microscope ....... 38

$5 \mathrm{c}_{2}$ gas laser ....................... 40

$6 \mathrm{CO}_{2}$ gas laser tube .................... 40

7 Partially reflecting mirror; camera shutter; polyethylene filter; test chamber........ 40

8 Test chamber; observation microscope ........ 40

9 Transmission electron micrograph; hollow seta; tarsus $1 ; 12,000 \mathrm{x} \ldots \ldots 42$

10 Transmisston electron micrograph; hollow seta; tarsus 1; 12,000x............ 42

11 Scanning electron micrograph; tarsus 1; anterior

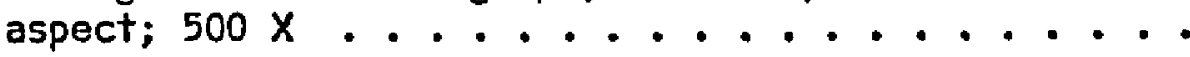

12 Scanning electron micrograph; tarsus 1; anterior aspect; $1,000 \times \ldots . . . . . . .44$

13 Scanning electron micrograph; distal end of tarsus 1; dorsal aspect; 2,000 X........ 46

14 Dorsal complex; tarsus 1; dorsal aspect ....... 48

15 Scanning electron micrograph; dorsal complex; tarsus $1 ; 2,000 x \ldots 50$

16 Scanning electron mlcrograph; dorsal complex; tarsus $1 ; 5,000 x \ldots \ldots . . . \ldots$ 


\section{LIST OF FIGURES (continued)}

Figure

17 Scanning electron micrograph; sigmold-shaped seta; tarsus 1; 11,200x......... 50

18 Scanning electron mlcrograph; sigmold-shaped seta; tarsus 1; gold coated; 18,000X ....... 50

19 Wavelength discrimination at $1_{+} \ldots . . . . . .52$

20 Tarsus 1; diagrammatic; dorsal aspect ........ 54

21 Receptor location; $\lambda=4.5 \mu$ at It........ 56 


\section{INTRODUCTION}

Detection of hosts, prey, or others of the same species has been attributed to a varlety of stimull (Camin, 1950; Hodgson, 1956; Braken, et al., 1962; Brown, et al., 1964). However, surprisingly little is known regardlng the sensory mechanisms Involved Burtt and Catton, 1960; Acree, et al., 1968; Ash, 1968; Machan, 1968). One of the most intriguing theories purporting to explain the detection processes in arthropods is the infrared radiation (IR) theory of communication. It is made all the more interesting when one considers that the $I R$ region is precisely that portion of the spectrum where a warm-blooded animal $\left(300^{\circ} \mathrm{K}\right)$ would emit radiation. In addition, molecules are known to emit characteristic radiation due to various vibrational and rotational energies and, as a consequence, complex molecules such as pheromones might also be sensed using IR emissions (Wright, 1963; Moncrieff, 1967).

The theory is not new but is unique because it presupposes the organism has a wavelength discrimination capability and does not respond only to changes in intenslty (cf. Bullock and Dlecke, 1956; Humphries, 1968; Warren and Proske, 1968). This does not Imply that wavelength discrimination is restrlcted exclusively to the $I R$ range (McEnroe and Dronka, 1966) or that an organlsm could not utilize two 
different portions (e.g., visible and IR) of the spectrum (Callahan, 1963).

If insects, which have been studied almost exclusively in regard to IR communication theory, can respond selectively to different wavelengths then it seems logical to assume that some $k \operatorname{lnd}(s)$ of receptor exists to recelve the IR radiation. To test this assumption, Grant (1949) made actual measurements of insect spines and as a result suggested the dielectric antenna as a possible mechanism for an IR receptor. Since that time, Callahan $(1965 a, b, c)$ has expanded on the theory and this receptor mechanism, and has demonstrated electrophysiologically (Callahan, 1968) that at least some insect spines are capable of functloning as IR receptors.

Opposition to the radiation theory has usually centered around IR emission from molecular sources (i.e., pheromones). One example is in regard to the assembling of moths for the purpose of mating. Kettlewell (1961) has supported the olfaction-pheromone concept and has found Laithwaite's (1960) conclusions that IR radiation does play a role in moth behavior completely untenable. However, nonpheromone sources have been implicated in assembling in at least one Insect. Congregation of a buprestld beetle, Melanophlla acuminata De Geer, to recently burned forest areas is apparently accomplished by IR sensitive areas on the thorax capable of wavelength discrimination. 


\section{IR Communication}

Electromagnetic waves are patterns of electrlc and magnetic flelds osclilating in mutually perpendlcular planes at right angles to the direction of movement. The electromagnetlc spectrum consists of radiation ranging from high frequency $(\bar{v})$ gamma rays to low frequency radio waves. Traditionally the spectrum has been divided into several different regions. The portion of the electromagnetlc spectrum extending from a wavelength $(\lambda)$ of $0.75 \mu$ to $2,500 \mu$ comprises the infrared region. It is further divided into the near $(0.75 \mu-2.5 \mu)$, intermediate $(2.5 \mu-25 \mu)$, and far $(25 \mu-2,500 \mu)$ infrared (Vasko, 1968). A common feature is that all the radlation, in a vacuum, travels at the same speed $\left(\mathrm{C}=3 \times 10^{8} \mathrm{~m} \mathrm{sec}^{-1}\right.$ ) but differs in trequency and wavelength. These quantities are related by:

$$
\lambda \bar{v}=\mathrm{C}
$$

Heat sources emit radiation because of increased temperature occurring in substances and the resulting emission is referred to as heat radiation. Solids and liquids emit continuous spectra whereas gases and vapors emit line or band spectra. Every body, then, with a temperature above absolute zero is capable of emitting radiation. The amount and spectral characteristics will depend on the absolute temperature of the object and upon its nature and surface finlsh. By definition a black body is any object which absorbs all radiation incident upon it and as a consequence will, at a given temperature, emit the maximum radiation possible. The emissivity factor, or radlating and absorbling efflciency, of a black body is unity. Most 
objects, however, have an emissivity factor below unlty and are termed gray bodles. As the temperature of a black body (or gray body) increases, the intensity of the radiation at all wavelengths increases rapidly. Wlen's Displacement law states that as the temperature of a black body Increases, the radlation peak shlfts to shorter wavelengths:

$$
\lambda_{m} T=K
$$

where $K$ is a constant with a numerical value of $2897.8 \mu^{\circ} \mathrm{K}$.

Luminescent sources (Vasko, 1967) are those in which the emitted radiation is Initiated by a means other than temperature Increase. An example is the absorption of another radiation as in a laser. The laser (Light Amplification by Stimulated Emission of Radiation) produces radiation having several different characteristics from that produced by thermal sources.

Molecular sources, as in the case of a $\mathrm{CO}_{2}$ gas laser, emit radiation when a transition is made between two vibrational or rotational energy levels (Pike, 19r7). An electrical discharge causes collisions to occur between energetic electrons and $\mathrm{CO}_{2}$ molecules. As a result, the molecules are excited to various vibrational levels. When more molecules exlst in the upper laser level than in the ground state, a population Inversion is said to have occurred. Lasing takes place during the de-excltation process as the molecule returns to a lower laser level. From the lower level the molecule returns to ground state. The efficlency of the $\mathrm{CO}_{2}$ laser can be increased by: 1) malntaining a high population Inversion and, 2) facllitating the 
de-excltation process so that the molecules are agaln ready to be exclted to the upper laser level (Patel, 1968). High population Inversion is ạlded by vibrationally excited nitrogen molecules. Hellum appears important in the two processes and both molecules are, consequently, added to the lasing medium. The resulting radiation emitted by the laser is predominately the $10.6 \mu$ wavelength. Conventional light sources in which the photons or quanta are emitted in a random fashion are classed as incoherent radiators. As such, a mixture of frequencies in different phases is produced. In contrast, lasers produce coherent radiation. Coherency Implies both temporal and spatial coherence.

Temporal coherence requires that each cycle of every wave takes the same amount of time to pass a given point. In essence, the frequency is the same and is termed monochromatic.

Spatial coherence necessitates having waves of the same frequency and in phase with each other in space (Pike, 1967). Coherency, therefore, implies both temporal and spatial coherence.

Transmission of electromagnetic radiation through the atmosphere is not always complete. Water vapor and carbon dloxide are the two most important attenuators or absorbers of radiation in the atmosphere (Hackforth, 1960). Varlous portions of the spectrum permlt most or all radiation to pass through and are known as atmospherlc transmission windows. One very large window in the intermedlate infrared occurs between $7.5 \mu-14 \mu$. Curlously enough, thls is precisely the range within whlch a warm-blooded animal could be expected to emlt its peak 
radiation according to equation 1 (i.e., at approximately $9.5 \mu)$. A parasite utilizing infrared radiation as a means of host detectlon might be expected to possess receptors whlch would be operable in this range.

A dielectrlc antenna or aerlal has been suggested as a structure which could function to recelve IR radlation. Klely (1953) has provided a most comprehensive study of dlelectric antennas and has defined them as primary radlators which employ a system of dielectric elements, as distinct from a system of conductors, to radlate electromagnetic energy or to collect radlated electromagnetic energy from one or more directions. It should be emphasized that all properties of transmitting antennas are also characteristic of receiving antennas even though the terminology used to describe these properties is conventlally that of a radiating antenna. If a dielectric antenna is expected to operate optimally it must possess certain structural as well as certain electrical properties. Most studies (Klely, 1953; Griffith, 1968) have Involved empirical measurements of actual models and the main emphasis here will be given to structural considerations of the hollow tube type of dielectric antenna.

Structurally, four properties describe a dielectric tubular antenna: dielectric constant $(\bar{\Sigma})$, diameter, length, and wall thickness. Since the inter-relationshlps of these properties have been thoroughly investlgated (Kiely, 1953; Griffith, 1968) and adequately sumarized (Callahan, 1967; Griffith, 1968) only a brlef outllne wlll be presented.

1. A high dlelectric constant would require a tube with thinner 
walls than a tube with a low dielectric constant because the electric path length in the wall would be greater in the latter case CKlely, 1953).

2. Tapering the antenna adds greatly to its oporating efficiency. Klely (1953), using polystyrene rods $(\bar{\Sigma}=2.5$ ) has provided appropriate formulae for the maximum and minimum dlameter $\left(D_{m a x}, D_{m l n}\right)$ necessary for this optimization:

$$
\begin{aligned}
& D_{\max }=\lambda_{0} / \sqrt{\pi(k-1)} \\
& D_{\min }=\lambda_{0} / \sqrt{2.5 \pi(k-1)}
\end{aligned}
$$

where $\lambda_{0}$ is the free space wavelength and $k$ is the dielectrlc constant.

3. The directionality of a dielectric antenna is proportional to the length and at an optimum length the resulting radiation pattern will be found to have one dominating lobe (the main lobe) and several smaller lobes (side lobes) and, it is desirable to have as little energy as possible in the side lobes. Six wavelengths appears about the optimal length (Griffith, 1968).

4. If wall thickness of the tube is at a critical value, which is a small fraction of the wavelength, for a particular value of $\bar{\varepsilon}$, then the radiation pattern will be essentially single lobed and the most likely mode, or pattern of oscillation, excited would be the hybrid $\mathrm{HE}_{\text {II }}$ mode (Kiely, 1953; Okress, 1965).

5. By combining a number of dielectric antennas the efficlency and performance of the detection system can be greatly increased. Such a set of antennas is called an array. 
The Behavior of Laelaps echldnina

Laelaps echldnlna Berlese, 1887 (FIg. I) is a blood sucking ectoparasite of rats. Females are ovoviviparous. Instars Include: larva, protonymph, deutonymph, and adult. All Instars feed except the larva (Owen, 1956). Presumably, the entire llte cycle is completed in the nesting materlal with host contact experienced only at times of feeding. Reynolds (1949) has indicated that mites exhiblt a tendency to form aggregations and to become qulescent until disturbed by changes in light intensity, air currents, substrate vibrations, $\mathrm{CO}_{2}$, and contact with moving objects. However, L. echidnina shows no response to gravity or directed light. Optimum temperature range for the mite appears to be $27-30^{\circ} \mathrm{C}$. Recent water balance studles (Wharton and Kanungo, 1962; Knülle, 1967) have shown the critical equilibrium activity of water vapor in the amblent air (the lowest point at which the organism can gain water from unsaturated air) to be $90 \%$. 


\section{MATERIALS AND METHODS}

\section{General Procedures}

A stock culture of $L$. echldnina was housed at the Acarology Laboratory, from whlch adult female mites were removed and standardIzed (Cross, 1954; Kanungo, 1964) prior to experImentation.

In order to observe a behavioral response of the mltes to IR It was necessary that they be in a quiescent state before exposure and, because of their slze, that they be viewed under magnification. This necessitated sultable test chambers and a means of partially restricting movement so that the mite remalned in the radiation beam.

A stopcock grease (Lubriseal), refrigerated at $1-2^{\circ} \mathrm{C}$, had excellent adhesive propertles and was apparently nontoxic to the test organisms. The adhesive was applied to the curled, pointed end of a minuten pin and the other end embedded into a cork. Individual mites were placed onto a cold stender dish cover and secured by the dorsal shleld to the tip of the pin. The cork-pin assembly was then placed into one of two types of test chambers.

The test chamber used in conjunction with the monochromator consisted of a one-dram glass vial with a rectangular opening cut across the vial and covered with transparent polyethylene behind which the mite was situated. The type used with the $\mathrm{CO}_{2}$ laser was a glass T-tube in which the Inslde dlameter was approximately equal to the 
diameter of the IR beam. The mite was suspended from the cork-pln assembly down the vertically positioned base of the " $T$ " so that the mite was directed into the beam. A plece of transparent polyethylene was placed over each of the remaining ends of the fube.

The duration of radiation exposure was controlled with a Wollensak self-cocking, varlable speed camera shutter. Exposure time, in all experiments, was restricted to 0.5 seconds with 60.0 second intervals between exposures or untll the test animal agal $n$ became qulescent.

In all experiments, except where noted, the procedure was to record the average percentage response of ten trials for each of ten Individuals for each wavelength and intensity tested. The response of the mite to $I R$, observed with the aid of a dissecting mlcroscope, consisted of extremely quick up and down movements of the legs immediately following exposure to IR. Responses of lesser magnitude were characterized by a distinct obllquely directed movement of one or both of the first pair of legs.

Illustrations which required the use of elther a compound or dissection mlcroscope were drawn with the ald of an ocular grid and ruled paper.

Photographs were taken with a Polarold Land camera, model 250, using black and white 3,000 speed fllm and flash attachment.

\section{Tarsus 1}

Removal of tars1. It has been demonstrated that tarsus 1, In the Acarl, has a sensory function (Farlsh and Axtell, 1966; Zolotarev and 
Elizarov, 1963). To investigate this possiblility in relation to $I R$ reception by $\underline{L}$. echidnina, a method of amputation was devised.

An adult female mite was first immobillized by aftaching its dorsal shield to a plece of masking tape. Tarsal amputations were accomplished by cauterizing the intersegmental membrane just proximal to the tarsus by the application of a sharp pointed, electrically heated, nichrome wire and removing the tarsus with a scalpel blade. All mites were held for twenty-four hours to observe the effects of amputation before experimentation was begun. After an experiment each amputee was mounted in Berlese's fluid on a glass slide to verify the degree of amputation.

Setal measurements. Setal measurements on tarsus 1 were taken using an ocular micrometer and light microscopy. Specimens for study were mounted in Berlese's medium and were made to lie flat by applying slight pressure to the cover slip. Particular setae were measured from either the left or right tarsus, since the variation among individuals could be expected to be greater than that between left and right tarsi on a given individual. Measurements were taken whenever possible and the results are presented in Tables 2 and 3 . In cases where data were Insufficlent for analysis, the individual measurements are given in parenthesis.

\section{Electron Microscopy}

Transmission electron 'microscopy. The preparation of material for study by transmission electron microscopy (TEM) followed standard 
TEM techniques (Wharton, et al., 1968), Observations and photographs were made with an RCA EMU3H electron microscope.

Scanning electron mlcroscopy. Mites were prepared for study by scanning electron microscopy (SEM) by two different methods, Specimens were affixed to a SEM observation stage by amyl acefate and coated by vacuum evaporation with $0.202 \mathrm{~g}$ of $\mathrm{Au}-\mathrm{Pb}(4: 6)$ alloy to glve surface conductivity. It was subsequently found that the coating procedure was not necessary for proper study and was therefore discontinued. Observations and photographs, unless otherwise noted, were made with uncoated material on a Cambridge Scanning electron microscope.

\section{Radiation Sources}

Monochromator. A Perkin-Elmer, model II2G, fore prlsm monochromator (Fig. 2) with ballasted power supply was used to provide monochromatic light. The source of radiation consisted of an electrically heated siliconcarbide rod (Globar) enclosed in a water cooled jacket and controlled by means of a Variac. The radiation was reflecfed by mirrors through a callbrated, movable extrance slit and onto a $\mathrm{KBr}$ salt prism. Since the model 1126 does not possess an exit slit, a portable slit was placed $8.0 \mathrm{~cm}$ from the fore prism component and was calibrated by attaching to it a $\mathrm{mlcroscope}$ stage $\mathrm{m} / \mathrm{crometer}$ (Fig. 3). It was thus possible to control the intensity of radlation to whlch the test anlmals were exposed as well as the width of the radiation beam. 
On the opposite side of the exit slit the test chamber and its holding apparatus were positioned directly in front of the silt opening (FIg. 4). Visible light from a low-pressure mercury vapor lamp was used to place the mite so that It would face directly into the IR beam.

Scanning the wavelengths from $1.0 \mu-14.0 \mu$, at an arbltrary intensity of $0.25 \times 10^{-3} \mathrm{w} \mathrm{cm}^{-2}$, revealed one wavelength $(4.5 \mathrm{\mu})$ to which the mites were most sensitive. Intensitles were measured with an Eppley thermopile and a Hewlett-Packard, model 425A, microvoltammeter and were subsequently controlled over the wavelength interval by opening or closing the entrance slit and setting the exit slit at $0.7 \mathrm{~mm}$. To determine the test intensity $\left(1_{f}\right)$, defined as the minimum intensity of radiation eliciting a $50 \%$ or greater response at the most sensitive wavelength, the intensity was changed approprlately and the percentage of response of the mites recorded.

Havelength discrimination was determined by exposing individuals to specific wavelengths at It at an exit slit of $0.7 \mathrm{~mm}$. The monochromator could not provide It at the longer wavelengths (i.e., $8.0 \mu-$ $14 \mu$ ) or at $1.0 \mu$. The wavelengths tested were those having good transmitting windows $(1.6 \mu, 2.2 \mu, 3.6 \mu, 4.5 \mu)$ and those having considerable attenuation $(4.3 \mu, 5.0 \mu, 6.0 \mu, 7.0 \mu)$ caused malnly by carbon dioxide and/or water vapor. An experlment was designed whlch deviated somewhat from the normal testing procedure: each of three mites was subjected to a set of three, randomly arranged, wavelengths $(3.6 \mu, 4.3 \mu, 4.5 \mu)$ such that each wavelength was tested ten times/mite. 
$\mathrm{CO}_{2}$ gas laser: $\mathrm{A} \mathrm{CO}_{2}$ gas laser (Flgs. 5,6 ) provided a source of coherent radiation at a wavelength of $10.6 \mu$. The apparatus consisted of a water cooled, low-pressure, gas filled tube located between two mirrors which form an optlcal cavity. The gas in the laser tube was a mixture of $10 \% \mathrm{CO}_{2}, 10 \% \mathrm{~N}_{2}$, and $80 \% \mathrm{He}$. Lasing action was initiated by applying an electrlcal discharge to the gas mixture. The pencllslze beam passed out the tube and through the partially reflecting mirror at one end. The camera shutter, polyethylene filter, and a test chamber were placed in sequence behind the mirror (Figs. 7,8 ). Defection of the beam for proper positioning of the mite was accomplished by means of UV light and special phosphor paper. 


\section{RESULTS}

\section{Electron Microscopy}

TEM findings indicate the presence of thin-walled sense organs on tarsus 1. Micrographs indlcate definite pores or apertures in the wall and also suggest the presence of at least two morphologlcally distinct types of setae in regard to arrangement and distribution of pores. In Flgure 9 the apertures are uniformly distributed but only along $180^{\circ}$ of the wall and dendritic processes appear to fill the entire lumen. The dendritic branches or neurofibrils (Fig, 10) of the second type appear partially restricted to a vestibular cavity or chamber at the proximal end of a tubular canal. The distal end of the canal opens to the outside. The pore openings in Figure 10 seem to be confined to a much smaller proportion of the total circumference than the previous type.

SEM mi crographs indicate a rather complex chaetotaxy (Figs. 11,12 ) on tarsus 1. With few exceptions, however, the superficial design of the setae appears to be remarkably similar. The base of the seta is completely surrounded by a raised cuticular ring but is separated from the ring by a shallow depression (Fig. 13). The depresslon appears to be of a more flexible nature, indlcated by the wrinkled appearance, than the ring. From the base, the setae taper uniformly to a finely pointed tip. Toward the distal end many of the setae are curved 
anteriorly. The coated materlal (Fig. 18) more clearly indicates the presence of narrowly spaced, thin vertical ridges which exhibit a spiral pattern along the length of the seta.

The setae of the "dorsal complex" (FIgs, 14,15) appear to lack the cuticular ring and depression and appear instead to be supported basally on a ralsed portion of the cuticle. Centrally located in the complex are three previously undescribed microsetae arranged in linear fashion and set in a deep depression. These mlcrosetae are flanked laterally by three hollow, thin-walled setae anterlorly and by two more posteriorly. The latter form a side wall of the depression and are directed over the three mlcrosetae in an anterior direction (figs. 15, 16).

A centrally located, sigmoid shaped seta also lacks the cuticular ring and depression and seems to fit flush with the tarsus. The bifurcate tip of the seta (Figs. 17, 18) is collared by a smooth, raised area which narrows anteriorly. The taper is not uniform and the outline appears triangular rather than circular.

\section{Test Intensity}

Preliminary scanning of the wavelengths from $1.0 \mu-14 \mu$ at $0.25 \times 10^{-3} \mathrm{w} \mathrm{cm}^{-2}$ Indicated that at $4.5 \mu$ the percentage response was $96 \%$ and was the wavelength to which the mites were most sensitive. By decreasing the intensity over the next two lower Intensities measured it was determined that the $1_{+}=0.16 \times 10^{-3} \mathrm{w} \mathrm{cm}^{-2}$. These results are presented in Table 1. 
TABLE

DETERMINATION OF TEST INTENSITY

\begin{tabular}{|c|c|c|c|c|c|}
\hline$\therefore$ & & SII & dth & $\therefore$ & \\
\hline $\begin{array}{c}\text { Test } \\
\text { No. }\end{array}$ & $\begin{array}{l}\text { No. } \\
\text { Trials }\end{array}$ & Entrance & ExIt & $\begin{array}{l}\text { Intensity } \\
\left(m w \mathrm{~cm}^{-2}\right)\end{array}$ & $\begin{array}{c}\text { Percentage } \\
\text { Response }\end{array}$ \\
\hline $\mathbf{I}$ & 10 & 2.0 & 0.5 & 0.25 & 96 \\
\hline 2 & 10 & 0.6 & 0.7 & 0.16 & 74 \\
\hline 3 & 10 & 0.5 & 0.7 & 0.08 & 41 \\
\hline
\end{tabular}

Wavelength Discrimination

Testing particular wavelengths at It revealed that the mites were able to discrimlnate among a number of different wavelengths (Fig. 19). The percentage of response to the two lowest wavelengths was negligible; $1 \%$ and $2 \%$ at $1.6 \mu$ and $2.2 \mu$ respectively. A marked increase in wavelength sensitlvity in which responses were above 50\% was demonstrated at wavelengths of $3.6 \mu(60 \%), 4.5 \mu(74 \%)$, and $5.0 \mu(51 \%)$. At the remaining wavelengths of $4.3 \mu, 6.0 \mu$, and $7.0 \mu$ in which there is decreased atmospheric transmission there was also decreased wavelength sensitivity. The percentage of response of the mites at these wavelengths decreased to $26 \%, 30 \%$, and $23 \%$ respectively.

The testing of one mite to three randomly arranged wavelengths resulted in percentages of response which were below those prevlously 
established for $3.6 \mu$ and $4.5 \mu$. These data are summarlzed here: $3.6 \mu-26 \% ; 4.3 \mu-10 \% ; 4.5 \mu-36 \%$. Prlor to experimentation the intensity at each wavelength was rechecked and, in addition, the original data does not suggest any procedural compllations which might have been responsible for the lower percentages of response. Subsequent to this experiment, the wavelength $4.3 \mu$ was tested singly under normal test procedure and the percentage of response was observed to be $26 \%$. Comparison of the percentages from the set of three wavelengths with those in which these wavelengths were tested separately indicates that both are in approximately the same proportions (random set $-26 \%-10 \%-36 \%$; individual expts. $-60 \%-26 \%-74 \%$ ). This might suggest that some factor(s) (e.g., unclean prism, moisture) other than experimental design was the cause of the discrepancy.

\section{Setal Measurements}

Results of setal measurements are given in Tables 2 and 3 . The setal numbers presented in column one of both tables refer to the setal numbers in Figure 20. Unfortunately, it was not possible to provide reliable wall thickness measurements. It is thought that the wall thickness of most of the hollow setae on tarsus I is probably less than $0.5 \mu$. 
TABLE 2

BASEE DIAMETERS ( $\mu$ ) OF HOLLOW

SETAE TARSUS I

\begin{tabular}{|c|c|c|c|c|c|}
\hline $\begin{array}{c}\text { Seta } \\
\text { No. }\end{array}$ & $\begin{array}{c}\bar{X} \\
(\mu)\end{array}$ & $\pm S D$ & $\mathrm{CV}$ & $\begin{array}{c}\text { Range } \\
(\mu)\end{array}$ & $n$ \\
\hline 1 & 2.2 & 0.14 & 6.52 & $2.0-2.4$ & 13 \\
\hline 2 & 1.9 & 0.15 & 8.03 & $1.7-2.0$ & 9 \\
\hline 3 & 2.3 & 0.16 & 7.21 & $2.0-2.4$ & 17 \\
\hline 4 & 1.9 & 0.10 & 5.32 & $1.8-2.1$ & 6 \\
\hline 5 & 2.3 & 0.11 & 4.80 & $2.1-2.5$ & 9 \\
\hline 6 & 2.1 & 0.11 & 5.13 & $1.9-2.2$ & 8 \\
\hline 7 & 2.1 & 0.24 & 11.29 & $1.7-2.3$ & 10 \\
\hline 8 & 2.2 & 0.09 & 4.25 & $2.0-2.3$ & 11 \\
\hline 9 & 2.5 & 0.12 & 4.80 & $2.3-2.7$ & 8 \\
\hline 10 & 2.4 & 0.11 & 4.79 & $2.2-2.6$ & 9 \\
\hline 11 & 2.4 & 0.11 & 4.90 & $2.2-2.5$ & 6 \\
\hline 12 & 2.2 & 0.17 & 7.74 & $1.9-2.4$ & 9 \\
\hline 13 & 1.8 & 0.16 & 9.15 & $1.6-2.1$ & 8 \\
\hline 14 & 1.5 & 0.05 & 3.27 & $1.5-1.6$ & 4 \\
\hline 15 & 2.2 & 0.13 & 5.85 & $2.1-2.5$ & 9 \\
\hline 16 & 1.8 & 0.12 & 6.67 & $1.6-2.0$ & 7 \\
\hline 17 & 2.8 & 0.18 & 6.59 & $2.6-3.1$ & 8 \\
\hline 18 & 2.6 & 0.11 & 4.31 & $2.4-2.7$ & 7 \\
\hline 19 & 2.7 & 0.05 & 1.83 & $2.7-2.8$ & 4 \\
\hline
\end{tabular}


TABLE 3

LENGTH $(\ddot{\mu})$ OF HOLLOW

SETAE TARSUS I

\begin{tabular}{|c|c|c|c|c|c|}
\hline $\begin{array}{l}\text { Seta } \\
\text { No. }\end{array}$ & $\underset{(\mu)}{\bar{X}}$ & $\pm \mathrm{SD}$ & $\mathrm{CV}$ & $\begin{array}{c}\text { Range } \\
(\mu)\end{array}$ & $\mathrm{n}$ \\
\hline $\mathbf{I}$ & 55.5 & 2.40 & 0.43 & $53.9-60.0$ & 6 \\
\hline 2 & 20.6 & 0.38 & 1.84 & $20.2-21.0$ & 7 \\
\hline 3 & 33.5 & 1.03 & 0.31 & $31.6-34.6$ & 14 \\
\hline 4 & 22.5 & 1.30 & 0.56 & $20.5-23.9$ & 5 \\
\hline 5 & 31.3 & 1.11 & 0.35 & $30.0-33.1$ & 6 \\
\hline 6 & 26.9 & 1.30 & 0.48 & $25.4-28.7$ & 6 \\
\hline 7 & 26.9 & 1.74 & 0.65 & $24.3-28.9$ & 7 \\
\hline 8 & 32.6 & 0.94 & 2.88 & $31.5-33.8$ & 6 \\
\hline 9 & 35.7 & 1.98 & 0.55 & $34.5-37.9$ & 3 \\
\hline 10 & 36.1 & 2.00 & 0.56 & $33.8-37.6$ & 3 \\
\hline 11 & 33.1 & 0.18 & 0.54 & $33.0-33.3$ & 3 \\
\hline 12 & 33.0 & 0.83 & 2.52 & $31.8-34.1$ & 8 \\
\hline 13 & 15.7 & 0.57 & 3.65 & $15.0-16.0$ & 3 \\
\hline 14 & $(11.8)$ & & & & 1 \\
\hline 15 & 32.1 & 0.48 & 1.49 & $31.6-32.7$ & 4 \\
\hline 16 & $(15.6$, & & & & 2 \\
\hline 17 & $(65.0)$ & & & & 1 \\
\hline 18 & 58.8 & 0.88 & 1.50 & $57.8-59.1$ & 5 \\
\hline 19 & $(60.0)$ & & & & 1 \\
\hline
\end{tabular}


The results of exposure to coherent radiation at $10.6 \mu$ and an Intensity at $0.3 \times 10^{-3} \mathrm{w} \mathrm{cm}^{-2}$ indlcate a $79 \% \mathrm{k}$ inetic response under normal testing procedure.

\section{Receptor Location}

A serles of experiments using the monochromator at a wavelength of $4.5 \mu$ at $1+$ was designed to try to determine the location of the infrared receptor(s). Because of the unique chaetotaxy of tarsus 1 and the relative non-ambulatory nature of legs 1 , the hypothesis was established that IR receptors are present on tarsus 1 . In the first experiment the mite was positioned, in the test chamber, so that it was perpendicular to the IR beam with legs 1 , excluding segments proxImal to the genu, completely out of the beam. Results (Fig. 21) Indicated essentially no response. A second experiment involved removal of tarsus 1 and the placing of the mite directly into the beam. The results of three of the 14 mites tested were discarded since their percentage of response was higher than that of a normal individual (i.e., non amputee) at the most sensitive wavelength $(4.5 \mu)$ at $I_{t}$. Subsequent microscopic comparison of the discarded mites with those included in the results revealed no apparent differences in degree of amputation. To check the effects of amputation on the percentage of response, the tarsus of leg IV was removed and a third experiment conducted. Five mites were tested and no differences were noted in either the quality or magnitude of response, but the percentage of those responding showed a definite decrease over a nomal Individual at the $4.5 \mu$ at It. A summary of these results is given in Figure 21 . 


\section{DISCUSSION}

Temperature CPeterson and Brown, 1951; Brown et al., 1964; Hodgson, 1956) or a change in background intensity CHumphreys, 1968, 1969) is at least in part responsible for a certaln behavioral response in an organism. Other workers (Evans, 1966a,b; Callahan, 1965f, 1967, 1968; Grlfflth, 1968) have suggested that some organisms, notably insects, have the capabllity of wavelength discrimination in the IR region. If the data presented are to be interpreted on the basis of existing knowledge and theory of IR communication in Insects (Callahan, 1968; Griffith, 1968) then definite criterla must be met. An effective communications system using incoherent radiation and operating in the near and intermediate IR region, necessitates the following: 1) the transmitting component (the rat) must have a temperature different from that of its surroundings, and 2) the temperature must provide an intensity at or above $I_{t}$ to which the receiver (the mite) could respond.

It has been demonstrated (Bullock and Dlecke, 1956) that the energy in calories emitted by a rat, $5 \mathrm{~cm}$ in radius, $50 \mathrm{~cm}$ from the receptor, and with a surface temperature $10^{\circ} \mathrm{C}$ above that of the receptor is $1.3 \times 10^{-5} \mathrm{cal} \mathrm{cm}^{-2} \mathrm{sec}^{-1}$ or $0.5 \times 10^{-4} \mathrm{w} \mathrm{cm}^{-2}$. The rat mite has been shown to respond to:

$$
I_{t}=1.6 \times 10^{-4} \mathrm{~W} \mathrm{~cm}^{-2}
$$


Comparison of intensity figures demonstrates that the intensity of the rat at $50 \mathrm{~cm}$ distance $1 \mathrm{~s}$ well below that required. However, $0.5 \mathrm{x}$ $10^{-4} \mathrm{w} \mathrm{cm}^{-2}$ represents the total intensity at all wavelengths emitted by the rat at a given distance. Equation 4, on the other hand, represents the intenslty at It at a particular spectral bandwidth for all wavelengths tested. In other words, the intensity which the mite recelves at a wavelength of $4.5 \mu$ must in fact be a small fraction of the total intensity emitted by the rat at a given dlstance.

The Stefan Boltzman law states that the total black body radlation measured in $\mathrm{w} \mathrm{cm}^{-2}$ of the radiating surface is a function of the fourth power of the absolute temperature of the source $\left(W=\delta T^{4}\right)$. For a gray body the equation must be amended to:

$$
W=\varepsilon \delta T^{4}
$$

where $\varepsilon$ is the emissivity factor of a gray body and $\delta=5.673 \times 10^{-12}$ $w\left(\mathrm{~cm}^{2} \operatorname{deg}^{4}\right)^{-1}$. Assuming an $\varepsilon$ of 0.9 for the rat, the radiant emittance emitted by the rat is approximately $44.2 \times 10^{-3} \mathrm{w} \mathrm{cm}^{-2}$. The fraction of the total intensity per unit wavelength interval at temperature $T\left(305^{\circ} \mathrm{K}\right)$ was determined by Planck's law and was found to be $5.0 \times 10^{-4}$ and $10.4 \times 10^{-4} \mathrm{~W}\left(\mathrm{~cm}^{2} \mu\right)^{-1}$ for the wavelengths $4.5 \mu$ and $5.0 \mu$ respectively. The actual wavelength interval or spectral bandwidth emitted at the exit slit $(0.7 \mathrm{~mm})$ of the monochromator was determined graphically (Perkin-Elmer Instruction Manual, 1952) to approximate $1.0 \mu(.966 \mu)$. With the above information it is now possible to estimate the distances over which the mite detection system could operate at a given wavelength at $I_{t}$. 
According to Lambert's law of cosines the amount of radiation from a radlating surface varies as the cosine of the angle between the detector and the normal to the surface. The distance that the detector is away from the source also influences the intensity received. The radlant intensity recelved at the detector is then:

$$
J=\frac{W A}{2 \pi d^{2}} \cos \theta
$$

where $W=$ total radiant emittance of the source; $A=$ area of the source. By the inverse square law the radiant intensity (J) varies Inversely as the square of the distance between the source and the detector. Thus, it is possible to estimate the distances over which L. echidnina could defect a rat at a particular wavelength interval. The value of $\mathrm{W}$ at $5.0 \mathrm{\mu}$ is $10.4 \times 10^{-4} \mathrm{~W} \mathrm{~cm}^{-2}$ and $\mathrm{J}=1+$. The detection angle of the mite in relation to the rat is taken to be $30^{\circ}$. The distance, $d$, can be calculated by transposing equation 5 and substifuting in the values: $W$ at $5.0 \mu=10.4 \times 10^{-4} \mathrm{w} \mathrm{cm}^{-2}, \mathrm{~J}=1$, $\theta$ (detection angle of the mite in relation to the rat) $=30^{\circ}$. The results indicate that at a wavelength of $5.0 \mu$ at $I+$ detection is possible at $16 \mathrm{~cm}$. At a wavelength of $4.5 \mu$ the distance decreases to approximately $12 \mathrm{~cm}$.

From the data summarized in Figure 19 it appears that the spiny rat mite can discriminate among a number of different $I R$ wavelengths. More importantiy, it appears able to accomplish this at en intensity which corresponds well with the intensity data obtalned from a rat and at what seems to be a realistic distance. If the mite does in fact have this differential capacity then it becomes of paramount interest to 
provide a reasonable explanation as to the nature of the sensory apparatus.

Microscoplc examination of the tarsal setae is one method or approach whlch can be used to determine, at least theoretlcally, whether or not the setae could function as IR receptors. MorphologIcally the setae would be required to meet cerfain structural requirements. Spatially, the arrangement and location of receptors could be expected to be on an area which would provide the most effective scanning of the environment.

SEM micrographs and Iight microscopy indicate that the hollow setae are tapered, curved toward the tip, and generally positioned in a forward direction which, as Callahan (1967) states, is another characteristic of a good dielectric antenna. Further analysis reveals a chaetotaxic arrangement which strongly suggests the possibility of arrays (e.g., setae 2 - 7, Fig. 20).

It is proposed that the hollow setae could function as hollow tubular dielectric waveguides operating in the infrared region of the electromagnetic spectrum. This assumption is based on the following setal characteristics:

1. The dielectric constant of insect cutlcle is given by Callahan (1968) to be between $2.5-3.0$. Based on the fact that Insect and mite cuticle appear identical structurally (Wharton, et al., 1968), a similar dielectrlc constant wlll be assumed for L. echldnina.

2. The radiation pottern of a dielectric antenna 15 more directive when the tube is tapered toward the free end. The setae are tapered. Taper formulae demonstrate a good fit for optimal operation. 
3. Length of the setae at a given wavelength closely approximates the operational optimum of six wavelengths.

The data given in Table 2 can now be applled to the appropriate structural design formulae. Formula 3 need not be considered since it represents the maximum minlmum diameter necessary for optimal functioning of a dielectric antenna. In the case of the setae under consideration, the tip diameter approaches zero and therefore is well within design limits (Griffith, 1968). In equation 2 let $\bar{\Sigma}$ be approximately mid-way (2.8) between 2.5 - 3.0. Transposing equation 2 yields:

$$
\lambda_{0}=D_{\max } \cdot \sqrt{\pi(k-1)}
$$

By using the $\bar{x}$ value for a seta from Table 2, as the value of $D_{\max }$ in the above equation, the optimal operating wavelength can be estimated. For instance, setae 2 and 4 (Table 2; Fig. 20) have a Dmax of $1.9 \mu$. Substituting this value into the equation, the wavelength is computed to be $4.51 \mathrm{\mu}$. Therefore a seta having a diameter of $1.9 \mu$ might be expected to function as a wavegulde at an optimal wavelength of $4.5 \mu$. Table 4 lists the optimal wavelengths for all setae measured. Comparison of these data with the percentage response at various wavelengths from Figure 19 is extremely intriguing. Responses were observed at $3.6 \mu, 4.3 \mu, 4.5 \mu, 5.0 \mu, 6.0 \mu$, and $7.0 \mu$. To each of these wavelengths, with the exception of $7.0 \mu$, there is, In Table 4, a wavelength of close approximation at a partlcular setal diameter for a particular value of $\bar{\Sigma}$. 
TABLE 4

WAVELENGTHS AT $D_{\max } ; \bar{\Sigma}=2.8$

\begin{tabular}{ccc}
\hline $\mathrm{D}_{\max }(\mu)$ & $\begin{array}{c}\text { Frequency of } \\
\text { Seta Measured }\end{array}$ & $\begin{array}{c}\text { Wavelength } \\
(\mu)\end{array}$ \\
\hline 1.5 & 1 & 3.56 \\
1.8 & 2 & 4.27 \\
1.9 & 2 & 4.51 \\
2.1 & 2 & 4.99 \\
2.2 & 4 & 5.23 \\
2.3 & 1 & 5.46 \\
2.4 & 2 & 5.70 \\
2.5 & 1 & 5.94 \\
2.6 & 1 & 6.18 \\
2.7 & 1 & 6.41 \\
2.8 & 1 & 6.65 \\
\hline
\end{tabular}

The optimal operating setal length for a dielectric antanna is glven by Griffith (1968) to be six wavelengths. Apparently, strict adherance to this value is not critical for the operation of a dielectric antenna. Klely (1953) states that as long as the ratio of antenna to wavelength is greater than $2.5(\bar{\Sigma}=6.0)$, the antenna will oparate with reasonable efficlency. The data from Table 3 Indicates that with the exception of one of nineteen setae measured, all are at least two and one half times the theoreflcal wavelengths given in 
Table 4. The length of seven of the nineteen setae measured, with base diameters $\left(D_{\max }\right)$ of $2.2 \mu-2.5 \mu$, were very close to the optimum length of six wavelengths.

Three points should be borne in mind in discussing the $\mathrm{CO}_{2}$ laser results. Firstly, a laser is Inherently a source of coherent, monochromatic electromagnetic radiation. The experimental $\mathrm{CO}_{2}$ laser emitted essentially one wavelength at $10.6 \mu$. Secondly, the Intensity was reduced to a level of $0.3 \times 10^{-3} \mathrm{w} \mathrm{cm}^{-2}$ but was almost twlce as high as the It established for L. echidnina. Thirdly, the response to the wavelength emitted by the laser may have absolutely no correlation with the fact that the mite exhibits a vigorous kinesls upon exposure to low concentrations of $\mathrm{CO}_{2}$ gas.

Water vapor and carbon dloxide play an important role in the biology of the spiny rat mite. Unlike black body radiation, which produces an even distribution of wavelengths, these molecular sources produce characteristic absorption band spectral lines which are the result of vibrational stretching of the molecule.

The present investigation hints at possible mechanisms, other than traditional chemoreception, for the sensing of $\mathrm{CO}_{2}$ by $\underline{\mathrm{L}}$. echidnlna. Callahan (1968) has proposed that scent molecules may exhibit maser-like action at or near the receptor site. Presumably the energy necessary for this phenomenon to take place would come trom the sun or the Insect itself. Masing could take place in elther the vestibular or tubular portions of the seta. Figure 10 indicates that there are present on tarsus 1 at least some setae havlng the appropriate conflguration. 
The second posslbility (Griffith, 1968) presupposes that the mite Is capable of sensing. one or several of the $\mathrm{CO}_{2}$ absorption bands. Sensory adaptation would enable the mite to become adapted to a particular level of background radlation. A further assumption is that the mite can detect a decrease in the background level at these wavelengths as the $\mathrm{CO}_{2}$ content of the air is increased. This system is made more attractive because it requires no additional input of energy. Essentially the carbon dioxide molecule functions as a broad or narrow (depending on the absorption band) band fliter. The percentage of response, or lack of it, (FIg. 19) at the center of a strong $\mathrm{CO}_{2}$ absorption band at $4.3 \mu$ may now have new significance. At a particular background intensity the mite could receive the wavelength of $4.3 \mu$ and respond by becoming akinetic. As $\mathrm{CO}_{2}$ is introduced into the environment by the rat there would be a decrease in background radiation at that wavelength. This system could account for the poor response observed at $4.3 \mu$.

Studies dealing with the sensory behavior of acarines have usually Implicated leg $\mid$ and specifically tarsus $\mid$ as having a sensory function (Camin, 1950; Farish and Axtell, 1966; Zolotarev and Elizarov, 1963; Varcammen-Grandjean, 1965). The present study also seems to suggest that tarsus I indeed has a sensory function. The palps are also thought to play a chemosensory role in acarlne behavior. Many of the palpal setae appear morphologically simllar to the hollow type found on tarsus 1. The results of the tarsal experlments (Fig. 21) would seem to indlcate that in terms of the wavelengths 
and intensity tested tarsi I possess the most effective IR receptors. However, It should be.kept In mind that if the palps are IR receptors, different wavelengths and intensities might be involved.

Integration and interpretation of data and theory may become more meaningful if they are discussed in terms of the kinds of activities in which an ectoparasite must engage and the kinds of stimull which confront it.

A rat can be considered a black body radlator or, more precisely, a gray body radiator. According to equation 1 at a body temperature of $305^{\circ} \mathrm{K}$ the wavelength of peak intensity would be $9.5 \mu$. This wavelength offers two distinct advantages for an organism using IR wavelengths to detect a warm-blooded host: 1) it is located in the center of a large atmospheric window, and 2) it is the wavelength of greatest intensity. Thus, it would seem rather puzzling for a host seeking organism to utilize shorter wavelengths at much lower intensities. However, it is proposed that this is apparently what the splny rat mite has done. For the mite to detect long wavelengths In the $9.5 \mu$ range, within the framework of the model presented, would require a seta having a base dlameter approximately twice as large as any hollow seta present on tarsus I. In addition, the It at the short wavelengths has been previously demonstrated to be effective in eliciting a response.

Structural requirements and their relationship to receptor locatIon may provide an additlonal clue as to why shorter wavelengths have been exploited. The first palr of legs are not involved continuously 
in ambulatory activity. Much time is spent with the legs held slightly above the body with the distal segments posltioned parallel to the substrate. The individual segments can only be moved in a vertical plane and the entire leg may be moved across a limlted horizontal plane. The result appears to be a highly moblle platform upon whlch are located the sensing elements for scanning the environment. The advantages of cbubling the setal diameters seem doubtful in terms of the spatial limitations of tarsus 1 and the possible resulting decrease in mobility.

The functioning of this detection system is undoubtedly related to the physiological state of the mite (e.g., fed or unfed) (ct. Camin, 1950; Wharton and Cross, 1957) and to the environmental conditions present just prior to detection. With these considerations in mind, a detection system such as the one described, if it operates at all, presumably does so with a reasonable degree of effectiveness. Since detection provides the parasite with information regarding the presence of a host it could be assumed that the distance interval between parasite and host would be the maximum possiole for optimal detection. A distance of $12-16 \mathrm{~cm}$ hardly seems large enough to allow a parasite (rat mite) sufficient time for detection, approprlate taxlc responses, and eventual host contact. Conversely, at greater distances the problem $\mathrm{mlght}$ be one of too much time. If the parasite could swiftly and accurately seek out the host perhaps a long range detection system would be quite effective. However, with long range detection coupled to a system in whlch chance plays a major role in eventual attachment, then prolonged precontact 
actlvity by the parasite might be expected to result in an unnecessary expenditure of energy. Therefore, the rat mite detection system has probably evolved to operate at a distance which allows the host to be sufficiently close for directional precontact activity to occur and thus ensures a minimal expenditure of energy with a maximal chance of contact.

One measure of an IR host detection system might be the effectiveness of species discrimination. The spiny rat mite system appears to lack the essential characteristics for host speclficity for the following reasons. The dielectric antenna is inherently a broad band device (Griffith, 1968), that is, it can operate over a number of frequencies other than the optimum. Certainly other rodents, Ilkely to gain entry into the nest, would release $\mathrm{CO}_{2}$, have a similar body temperature, and emit the same characteristic IR wavelengths as the normal host. From this standpoint, it does not seem I ikely that this particular system is very host specific. According to Strandtmann and Wharton (1958), L. echldnina has been recorded from at least six specles of rats. The problem then is whether or not the "wrong" host enters the rat nest and, if so, how often. Such data was not found to be avallable but it would seem probable that the chances of wrong host entry are low. If most of the time the normal host enters the nest, then the detection system need only supply information relating to host presence and direction. 


\section{SUMMARY}

Adult females of the spiny rat mite, Laelaps echionina, are able to discriminate wavelengths of Incoherent and coherent IR radiation. Using a monochromator as a source of incoherent radlation, eight wavelengths in a range from $1.6 \mu-7.0 \mu$ were compared at a test intensity of $1.6 \times 10^{-4} \mathrm{w} \mathrm{cm}^{-2}$. Kinetic responses of indlviduals which were above $50 \%$ were observed at wavelengths of $3.6 \mu(60 \%)$, $4.5 \mu(74 \%)$, and $5.0 \mu(51 \%)$; below $50 \%$ were at wavelengths of $4.3 \mu(26 \%), 6.0 \mu(30 \%)$, and $7.0 \mu(23 \%)$. Essentially no response was elicited at wavelengths of $1.6 \mu$ and $2.2 \mu$.

$A \mathrm{CO}_{2}$ gas laser provided a source of coherent IR radiation at a wavelength of $10.6 \mu$. A kinetic response of $79 \%$ was observed at an intensity of $3.0 \times 10^{-4} \mathrm{w} \mathrm{cm}^{-2}$.

It was determined that the receptors which receive these wavelengths are located primarlly on tarsus 1. The basis for this conclusion is that if tarsi I were positioned out of the beam or if they were amputated, the percentage of response, at the most sensitive wavelength $(4.5 \mu)$ at $I_{t}$, decreased to $3 \%$ and $8 \%$ respectively.

It is proposed that the receptors of IR radlation are the hollow setae on tarsus 1 and that they function as dielectric antennas. This is supported by the close approximation of the expected characteristics, such as dielectric constant, base diameter, length, and 
taper, of an optimally designed dielectric antenna with the observed characteristics of the hollow setae on tarsus 1 .

The fact that the spiny rat mite can detect and discriminate among different wavelengths of $I R$ radiation in the laboratory becomes more significant when viewed in terms of the kinds of activities in which a host-seeking parasite must engage. One of the most important problems with which the mite must deal is how to detect and attach to the host with a minimum expenditure of energy. It is here suggested that while the lower wavelengths are not those of peak Intensity, they do allow for smaller receptor dimensions to be utillized and at an Intensity to which the spiny rat mite is able to respond. 
Figure 1. Venter of the female of Laelaps echidnina Berlese 


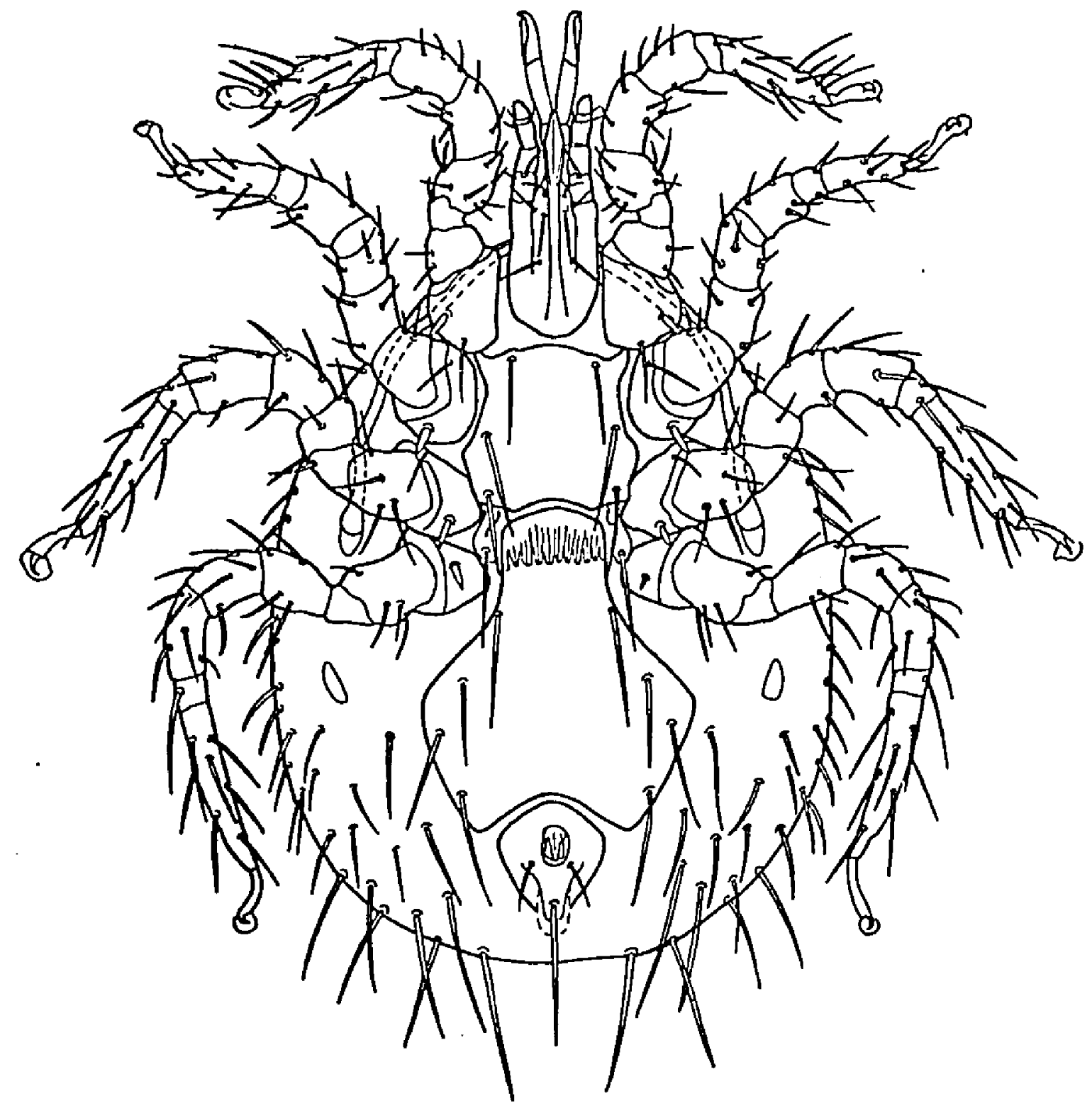

1 
Figure 2. Perkin-Elmer monochromator model II2G;

Globar source (left) and fore prism component (right)

Figure 3. From left to right - Monochromator fore prism component, camera shutter, exit slit, and test chamber; viewed from above

Figure 4. Monochromator fore prism component, camera shutter, exlt slit, and test chamber; observation $\mathrm{ml}$ croscope; viewed in sequence from back to front 

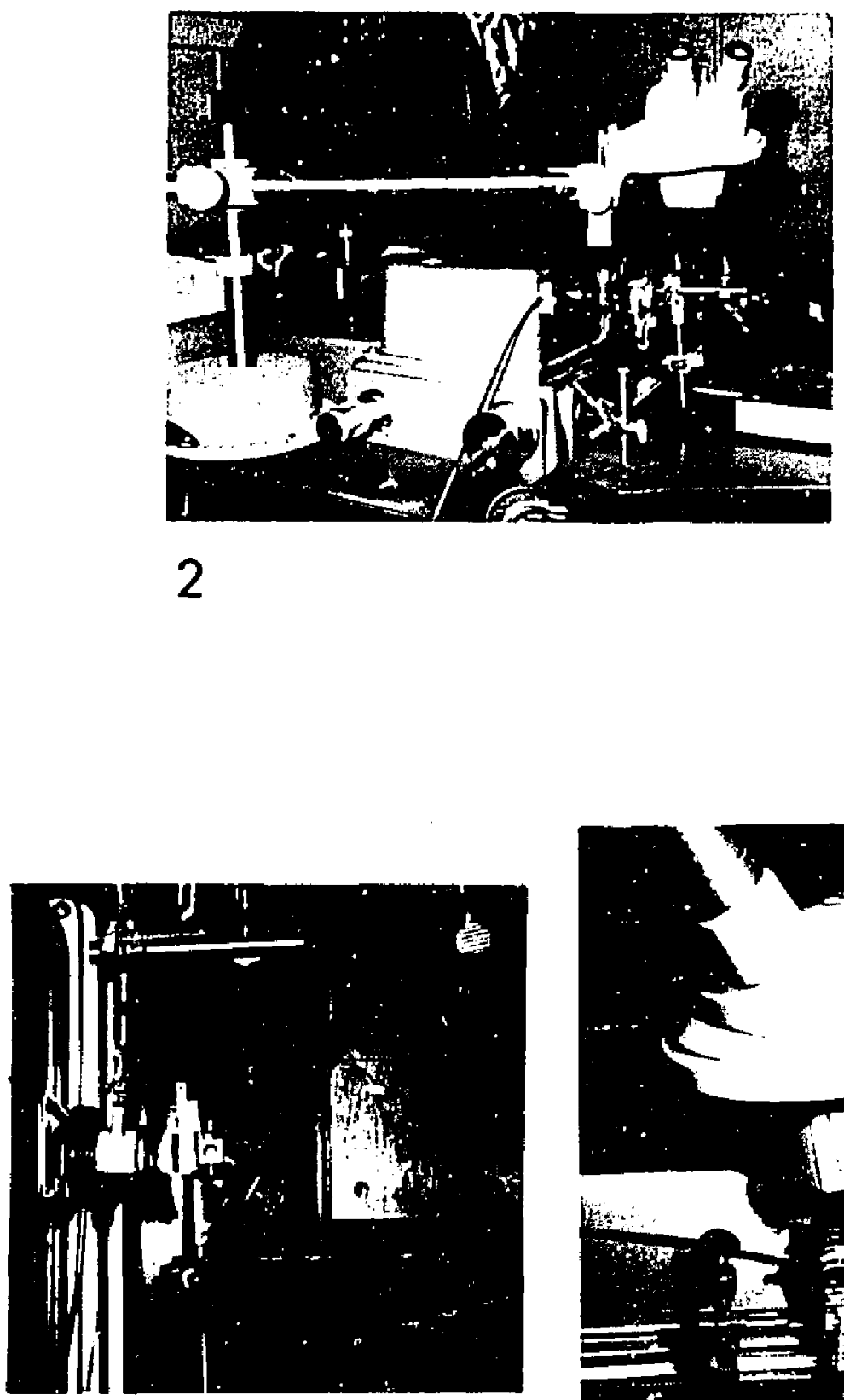

3

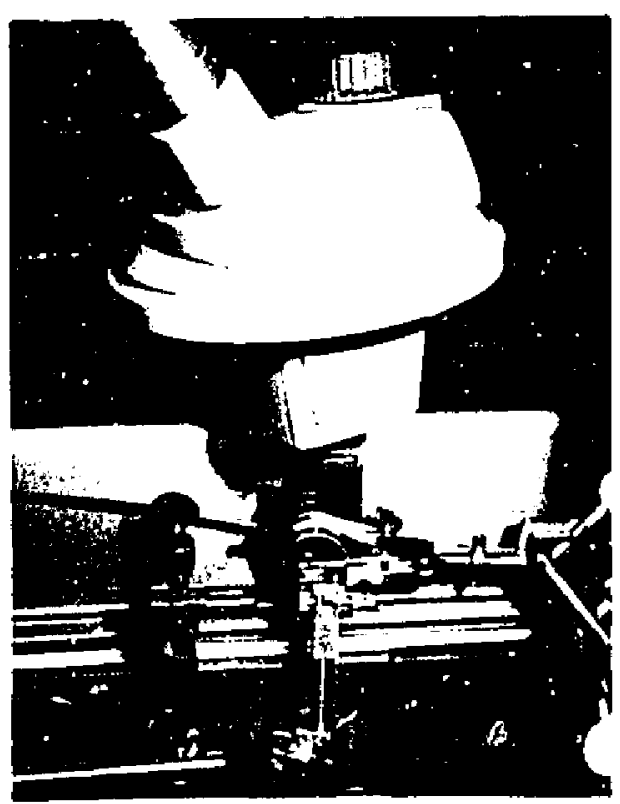

4 
Figure 5. From left to right $-\mathrm{CO}_{2}$ gas laser, partially reflecting mirror, and testing apparatus; lateral view

Figure 6. $\mathrm{CO}_{2}$ gas laser tube; viewed from above

Flgure 7. From left to right - Partlally reflecting mirror, camera shutter, polyethylene filter, and test chamber; viewed from above

Figure 8. From left to right - Camera shutter, polyethylene filter, and test chamber; observation microscope; lateral view 

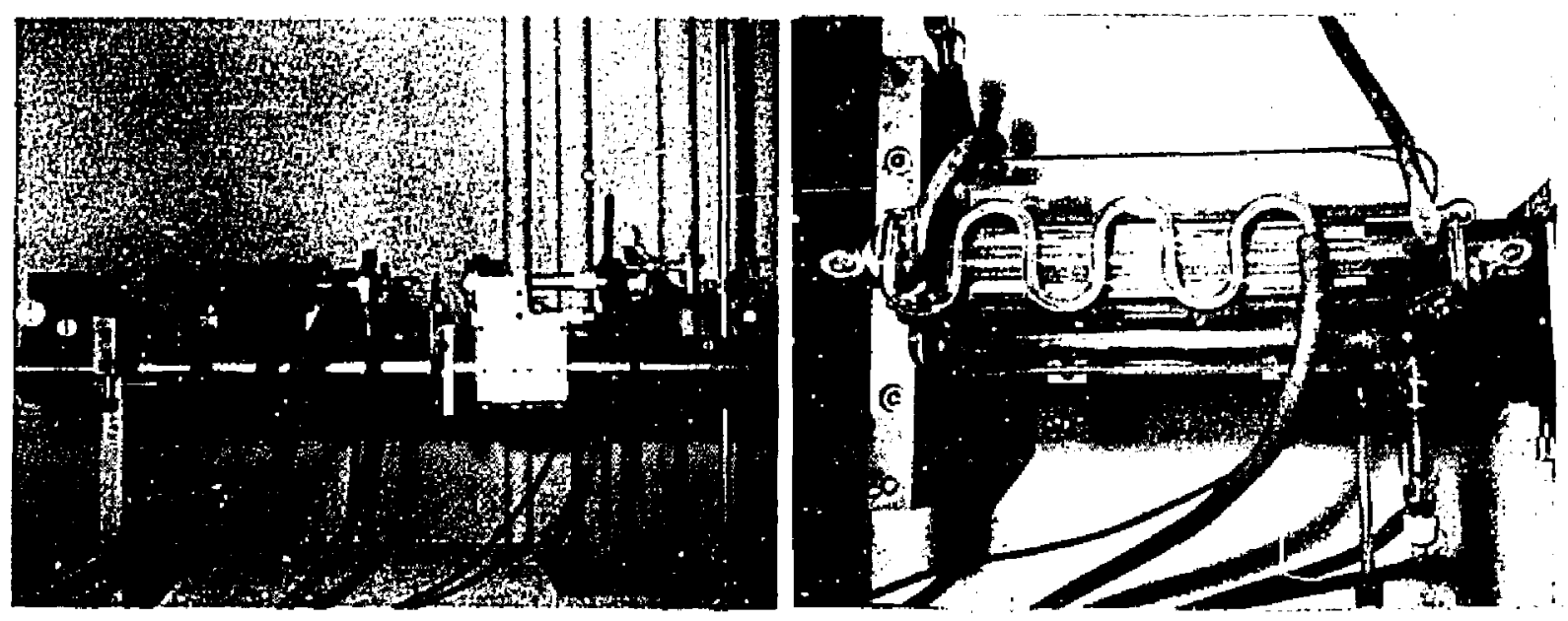

5

6

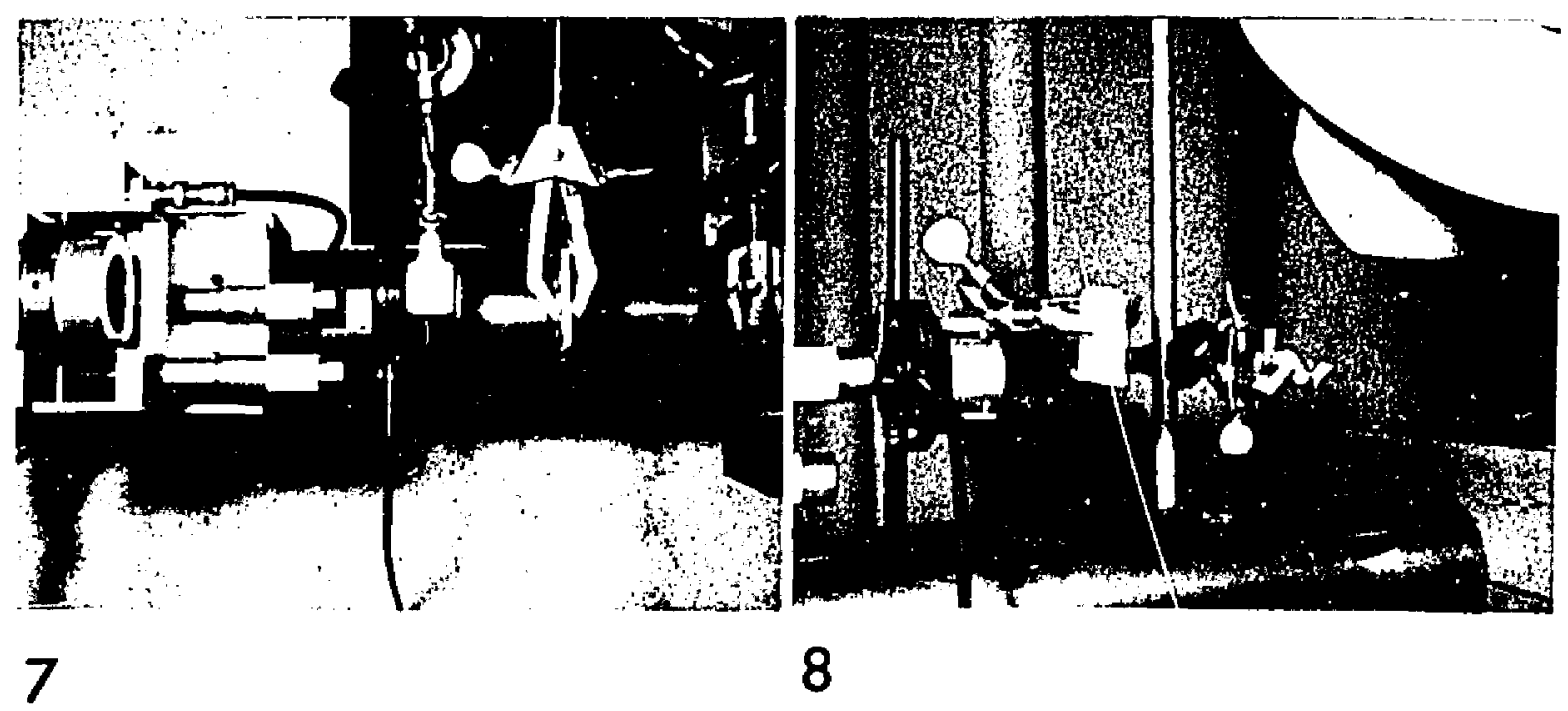


Figure 9. Transmission electron micrograph; hollow seta; tarsus 1; 12,000 X; Note distribution of apertures

Figure 10. Transmission electron micrograph; hollow seta; tarsus 1; 12,000 X; Note distribution of apertures 

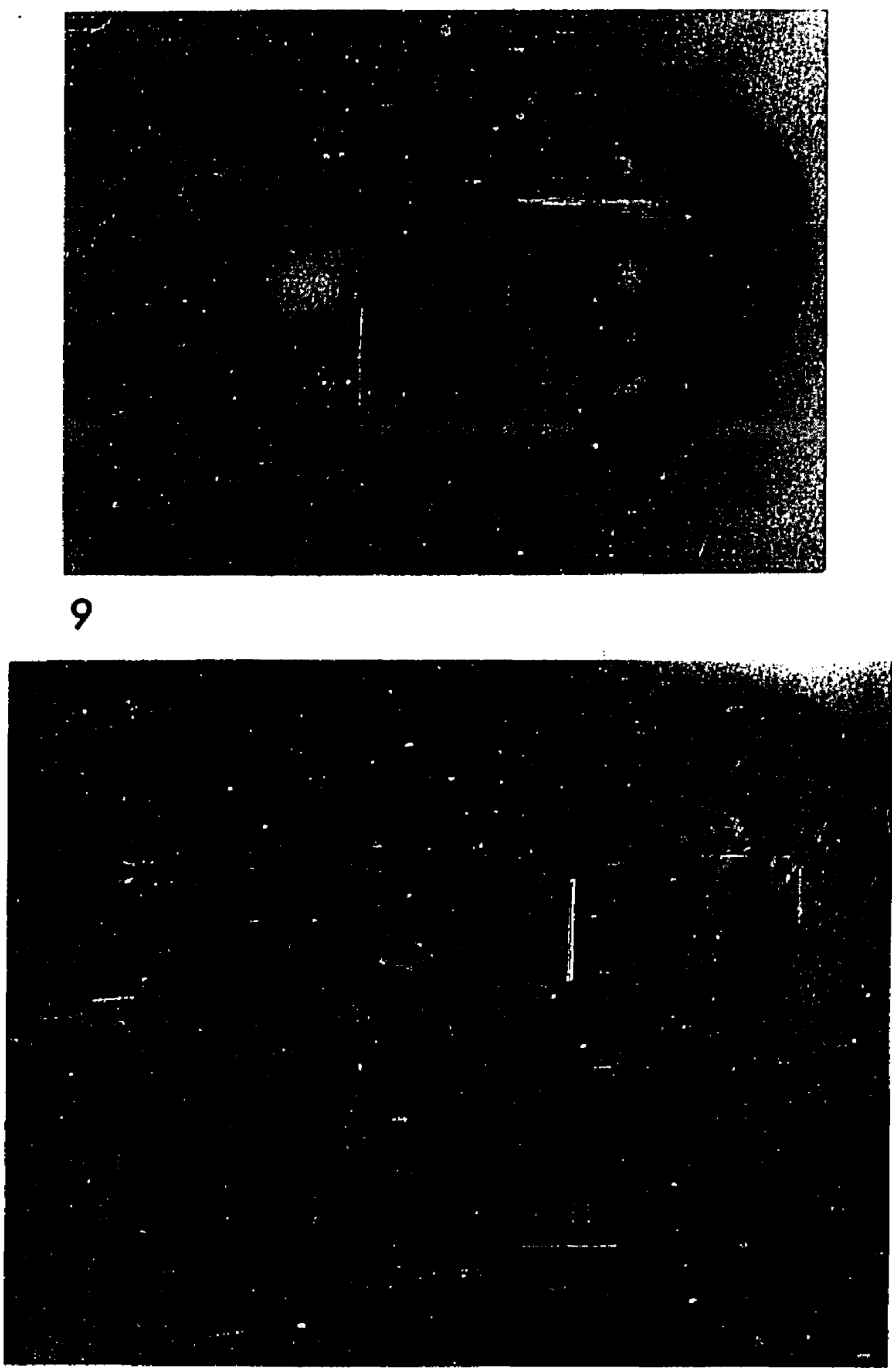

10 
Figure 11. Scanning electron micrograph; distal portion of left tarsus 1; en face view; $500 \mathrm{X}$

Figure 12. Scanning electron micrograph; distal portion of left tarsus 1; en face view; 1,000 X 


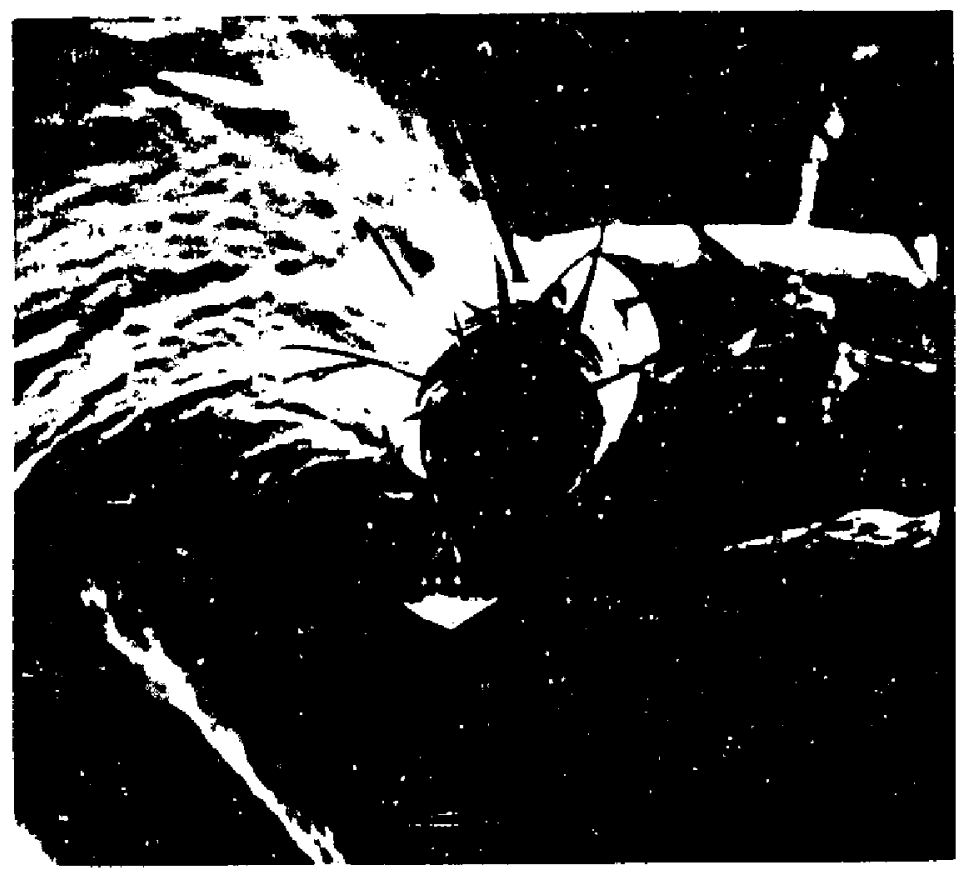

11

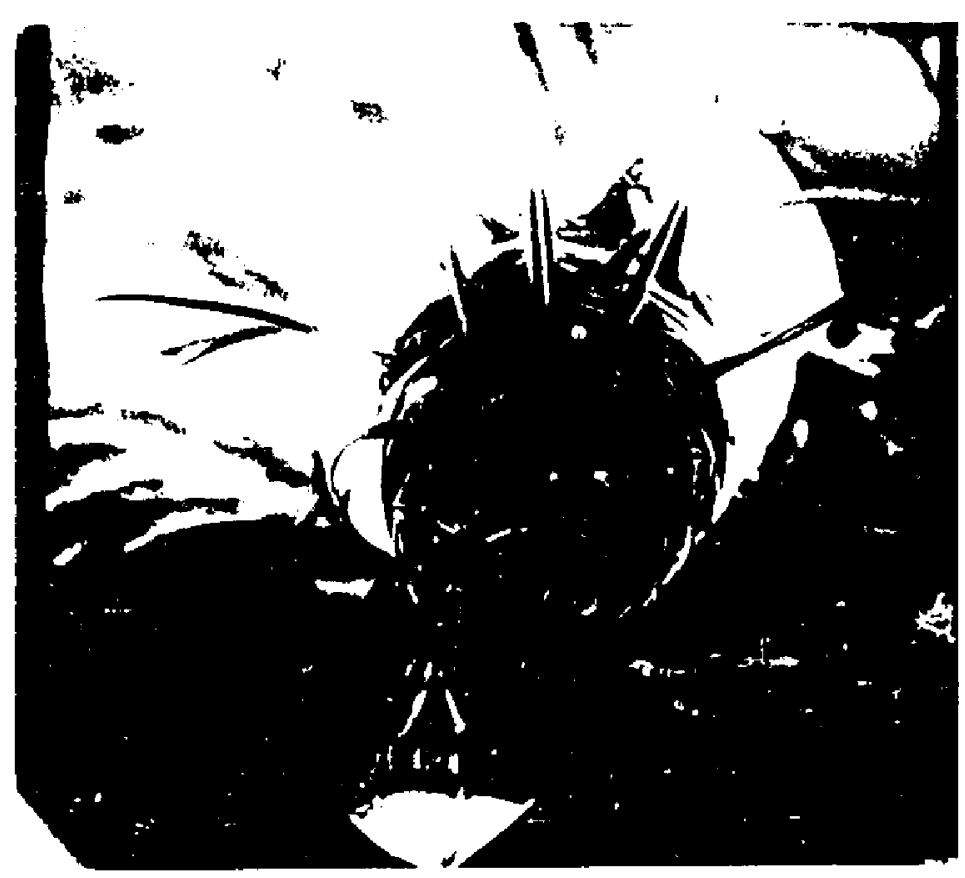

12 
Figure 13. Scanning electron micrographs; distal portion of left tarsus 1; dorsal aspect; 2,000 X. CTo vlew micrographs in three-dimensions, hold a small mirror against the right slde of the nose about six inches above the large dot. Focus the left eye on the left picture and adjust the mirror until the reflected image of the right picture merges with the left) 
$\vec{\omega}$
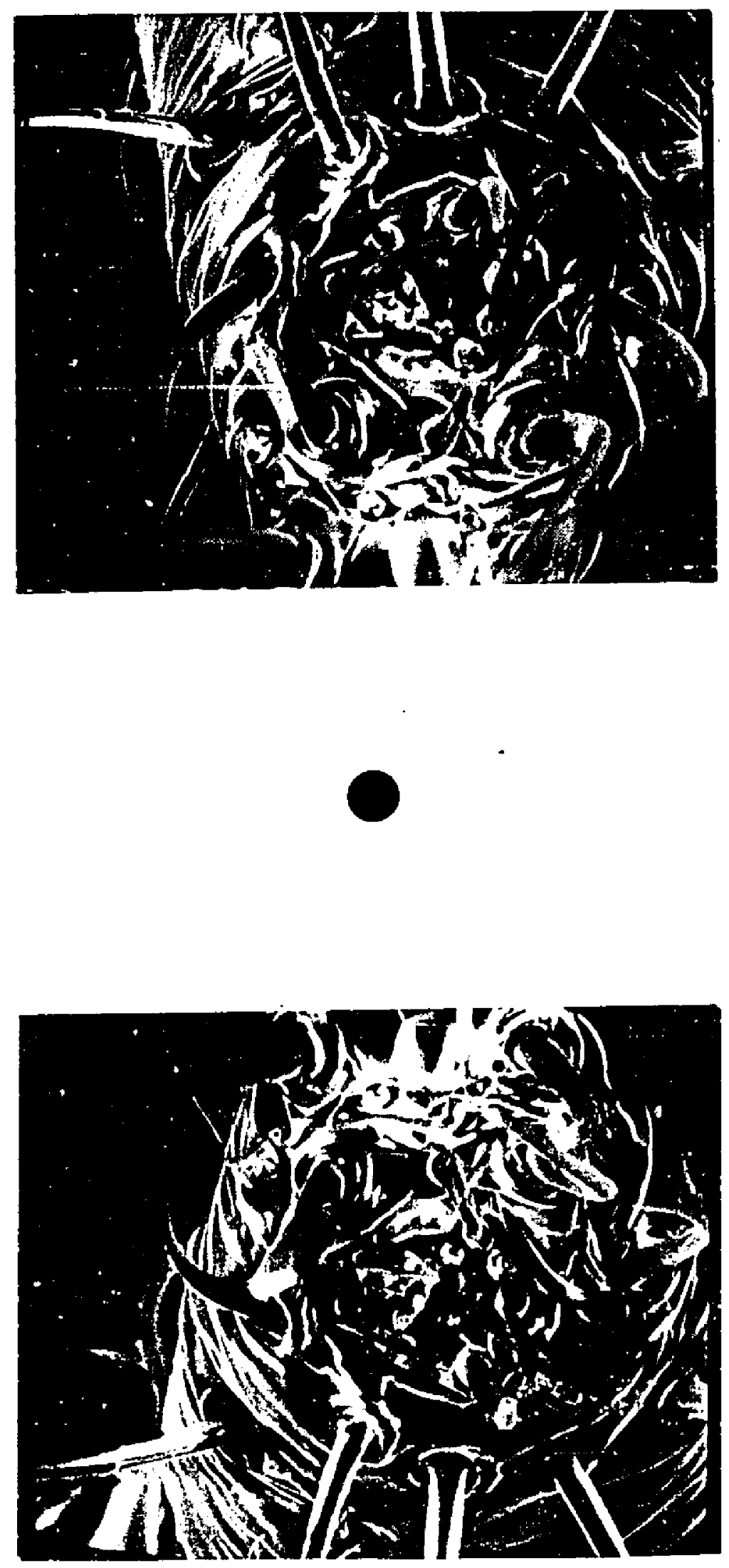
Figure 14. Dorsal complex; distal portion of left tarsus 1; dorsal aspect; scale equals $5 \mu$ 


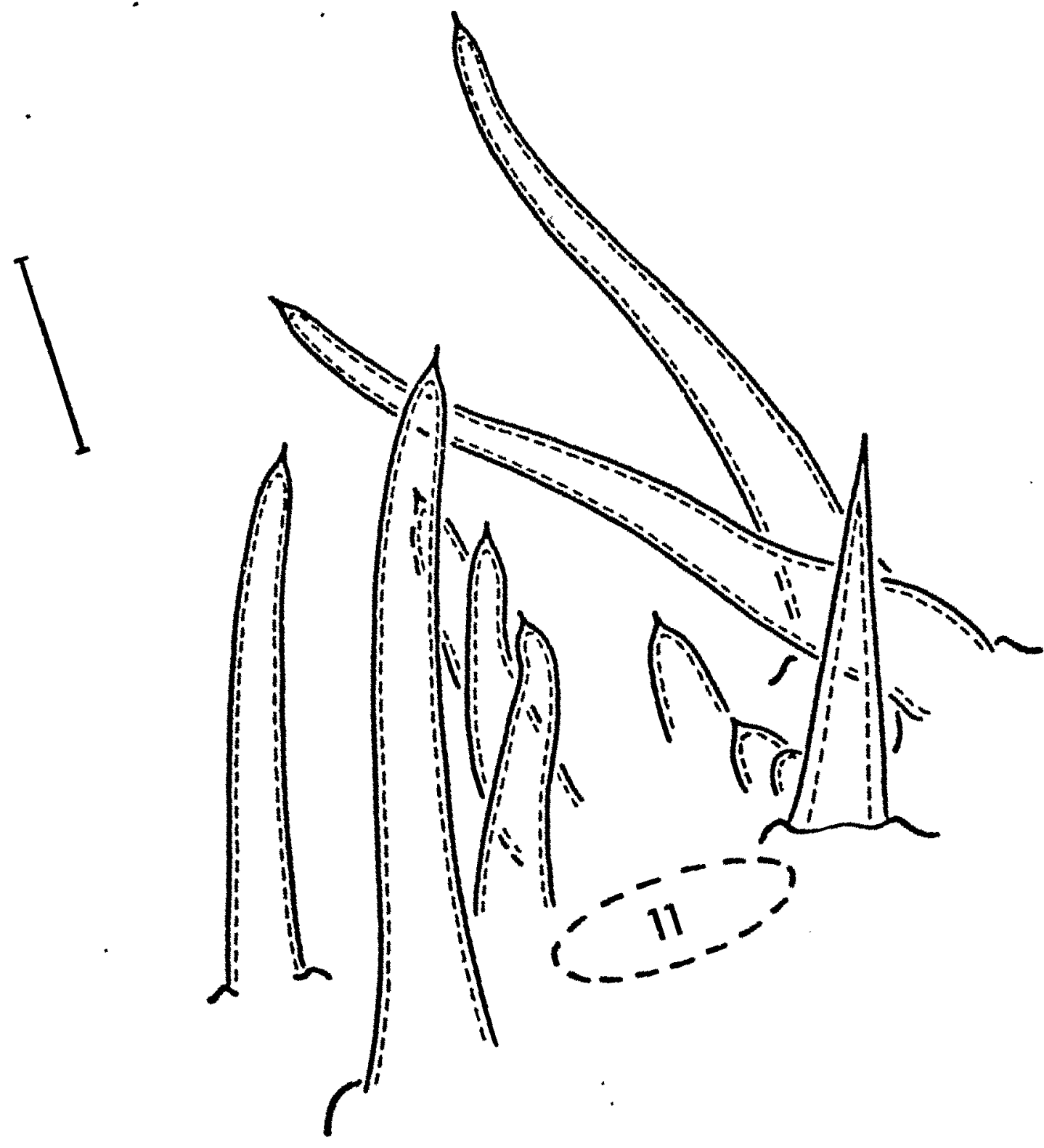

14 
FIgure 15. Scanning electron micrograph; distal portion of right tarsus 1; dorsal aspect; 2,000 X

Figure 16. Scanning electron mlcrograph; microsetae of dorsal complex; distal portion of right tarsus 1; dorsal aspect; 5,000 X

Figure 17. Scanning electron micrograph; sigmoidshaped seta; distal portion of tarsus 1; lateral aspect; $11,200 \mathrm{x}$

Figure 18. Scanning electron micrograph; sigmoldshaped seta; distal portion of tarsus 1; lateral aspect; gold coated; $18,000 \mathrm{X}$ 


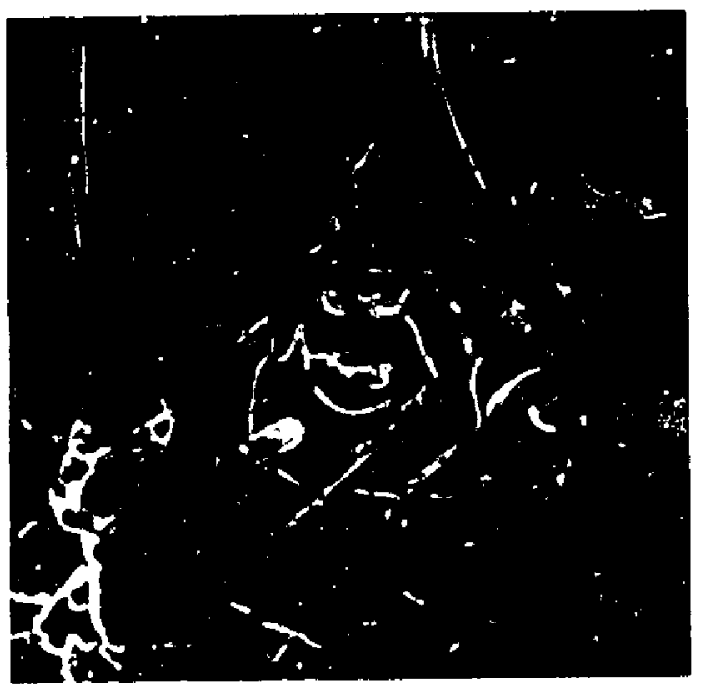

15

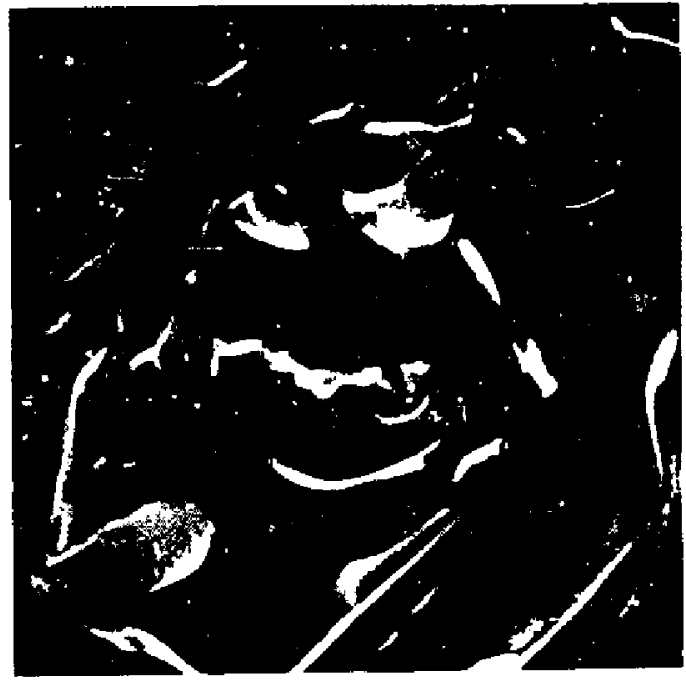

16
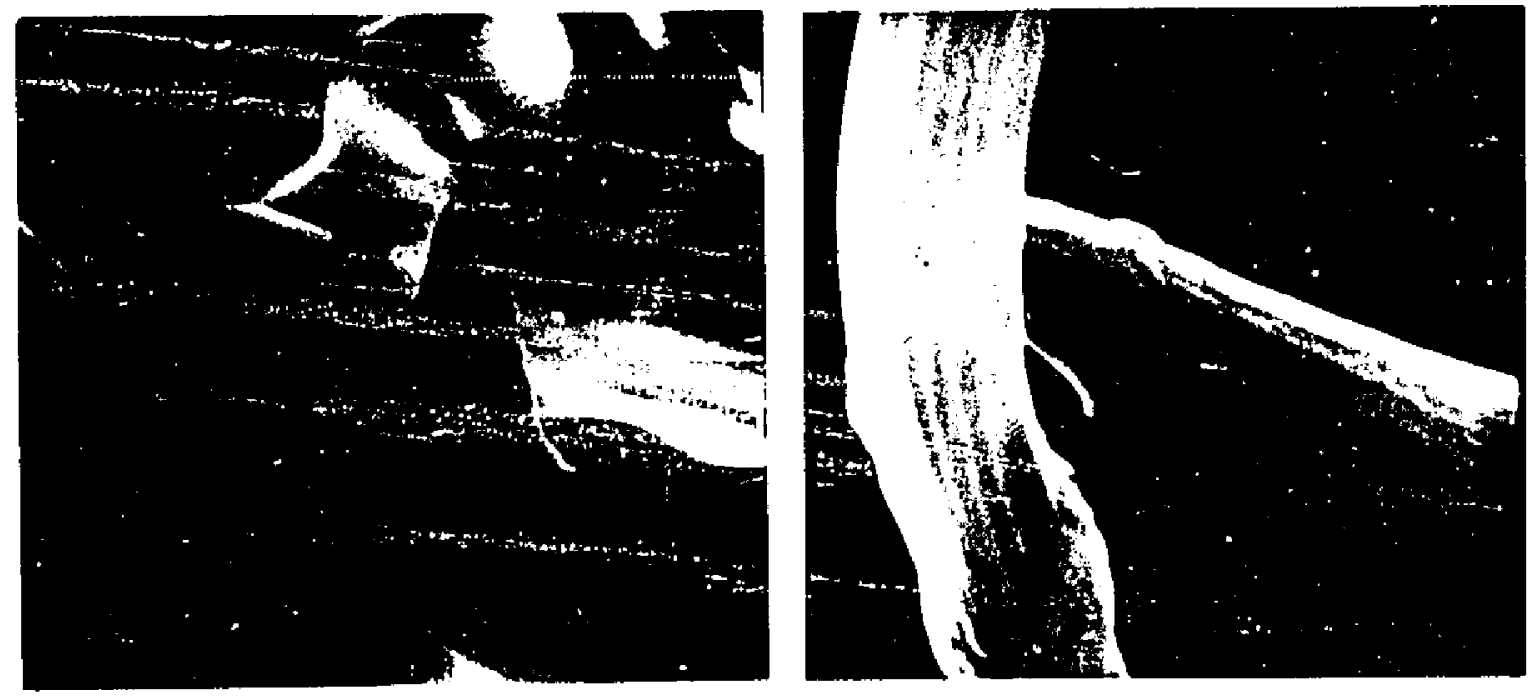

17

18 


\section{Flgure 19. Wavelength discrimination at I+; \% response vs, $\lambda$}




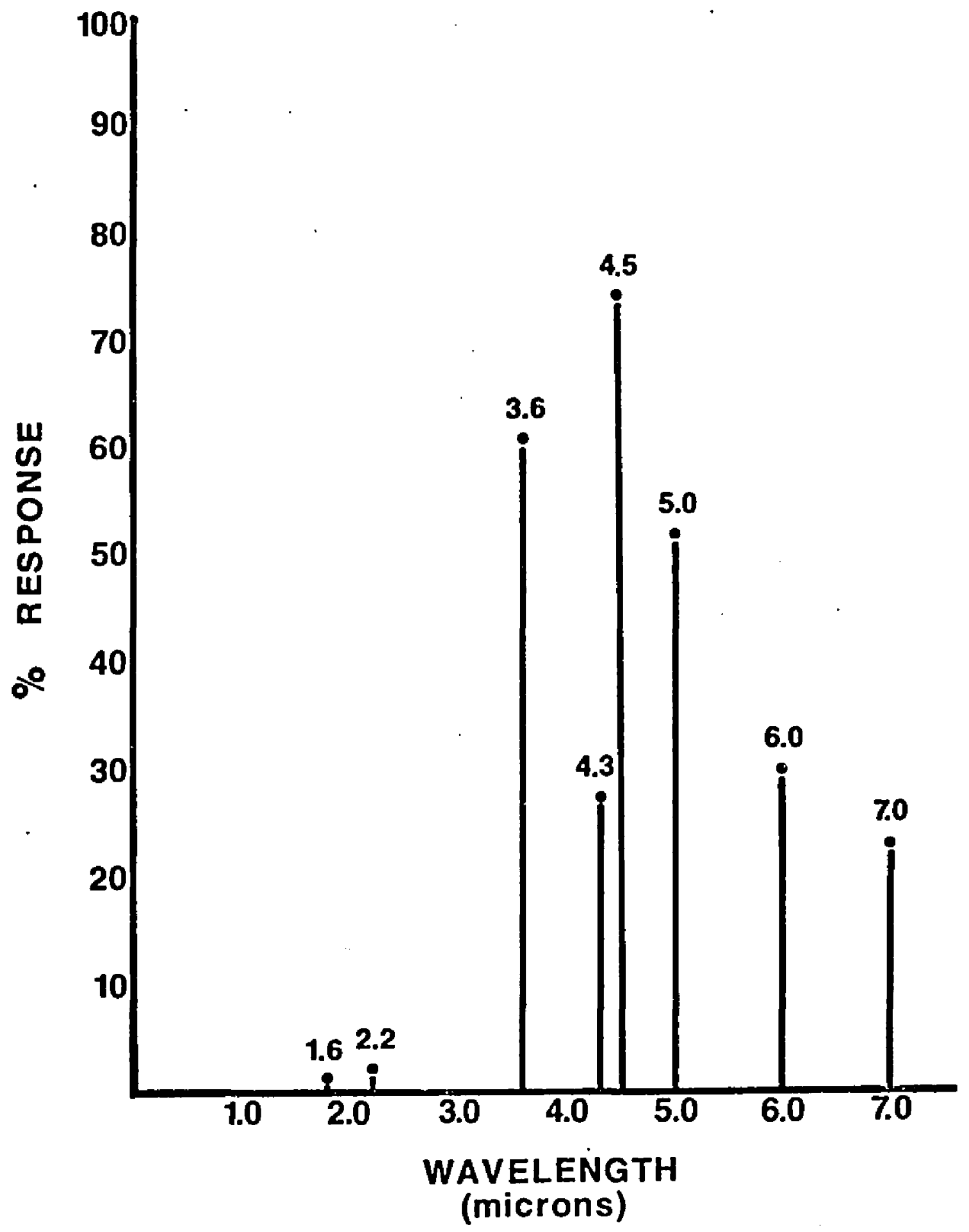


Figure 20. Tarsus 1; diagrammatic; dorsal aspect;

numbers correspond to setae measured

$$
\begin{aligned}
& \text { dorsal setae } \\
& \text { ventral setae }
\end{aligned}
$$




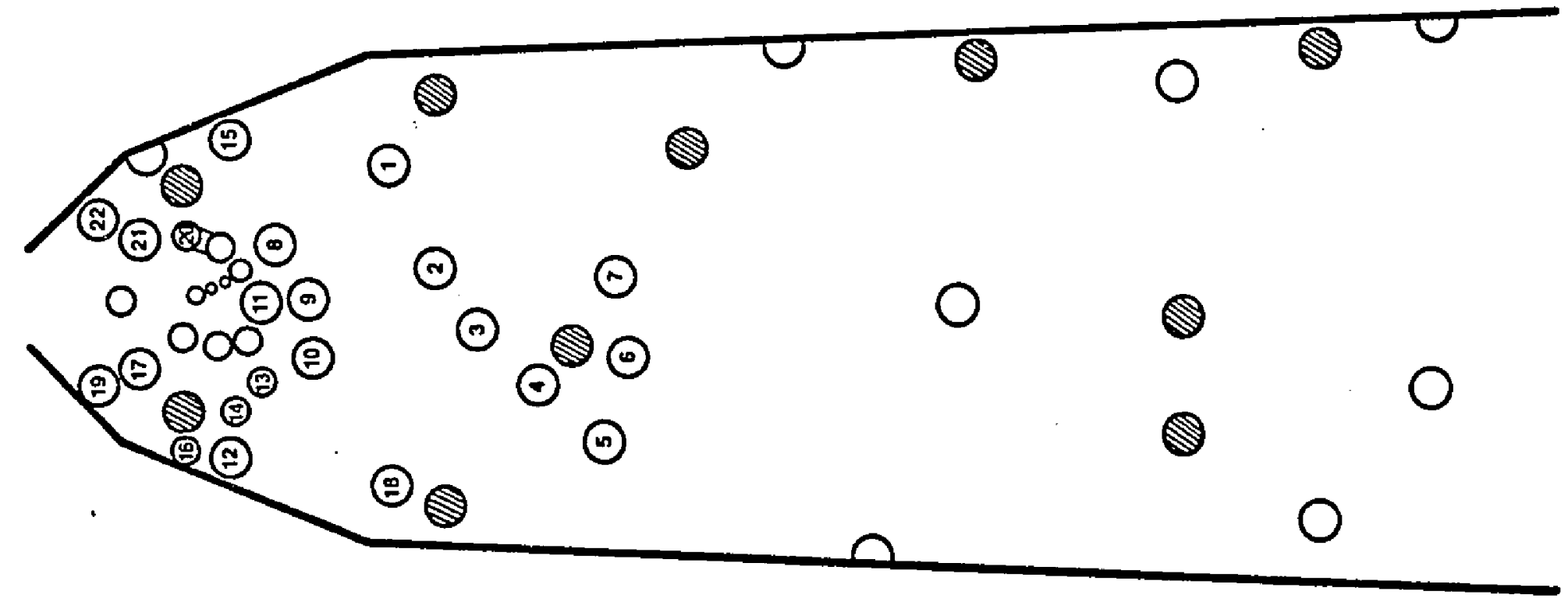

i 
Figure 21. Infrared receptor location; wavelength -

4.5 at $1+; \%$ response vs. type of mite

$$
N=\text { normal female }
$$

$T r_{4}=$ tars I IV removed

$T r_{1}=$ tarsi 1 removed

$P=$ normal female positioned

perpendicular to IR beam;

$\log 1$ not in beam 


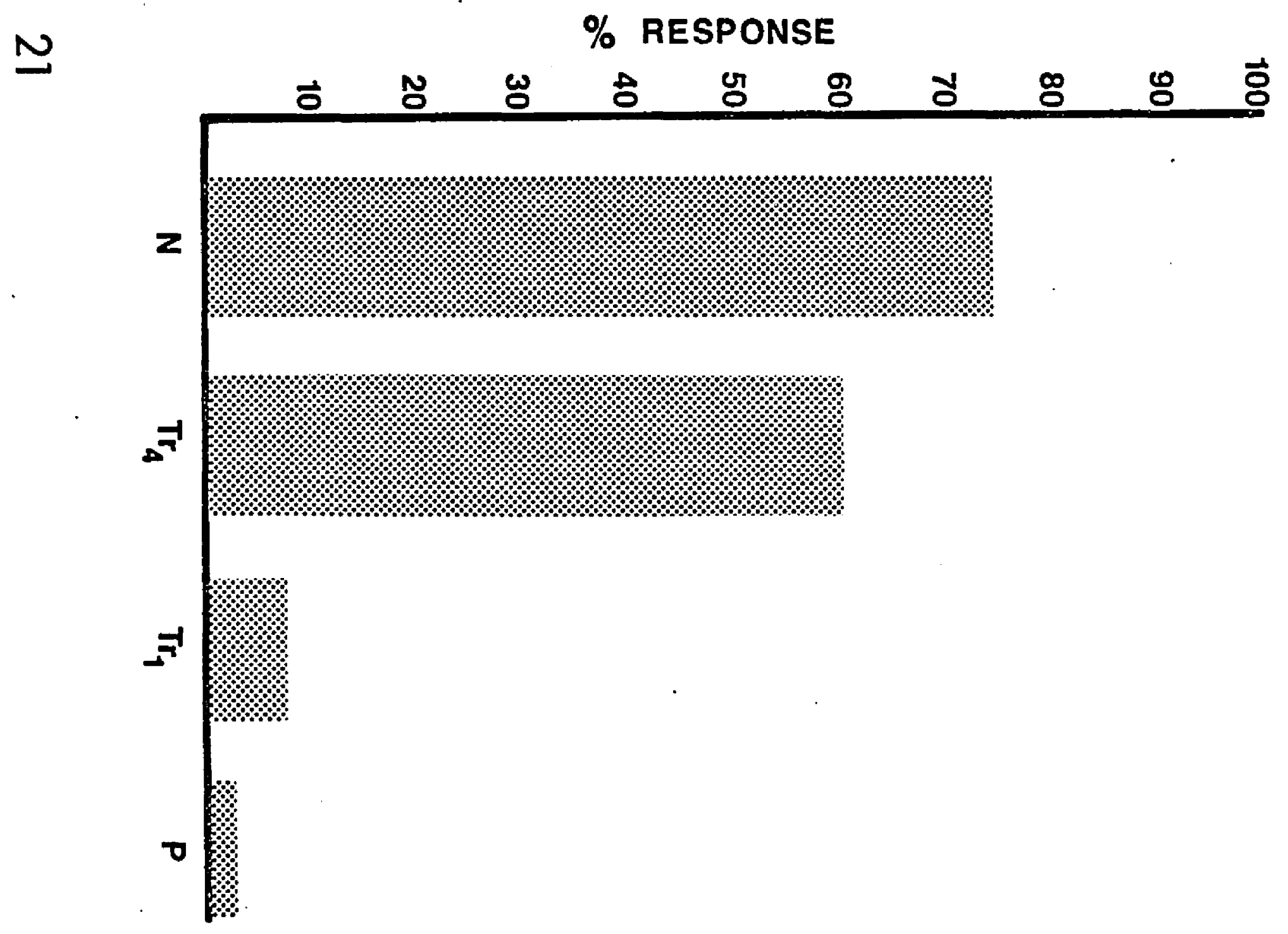




\section{LITERATURE CITED}

Acree, F., Jr.; R.B. Turner, H.K. Gouck, M. Beroza, and N. Smlth. 1968. L-lactic acid: A mosquito attractant isolated from humans. Scl. $161: 1346-1347$.

Ash, K.G. 1968. Chemlcal sensing: An approach to blologlcal molecular mechanisms using difference spectroscopy. Scl. 162:452-454.

Bracken, G.K., W. Haneck, and A.J. Thorstelnson. 1962. The orientation of horse $f$ lies and deer $f$ lies (Tabanidae: Diptera), 11 . The role of some visual factors in the attractiveness of decoy sllhowettes. Can. J. Zool. 40:685-695.

Brown, A.H.A., H.P. Roessler, E.Y. Llpsitz, and A.G. Carmichael. 1964. Factors in the attractiveness of bodies for mosquitoes. Can. Entomol. $96(1-2): 102-103$.

Bullock, T.H. and F.P.J. Diecke. 1956. Properties of an infra-red receptor. J. Physiol. 134:47-87.

Burtt, E.T. and W.T. Catton. 1960. Is the mosaic theory of insect vision correct? XI Int. Congr. Entomol., Proc. 1:670-673.

Callahan, P.S. 1965a. Intermediate and far Infrared sensing of nocturnal insects. Part I: Evidences for a far infrared (FIR) electromagnetic theory of communication and sensing in moths and its relationship to the limiting biosphere of the corn earworm, Hellothis zea. Entomol. Soc. Amer., Ann. 58(5):727-745.

Callahan, P.S. 1965b. Far infra-red emission and detection by nightflying moths. Natur. 206:1 172-1173.

Callahan, P.S. 1965c. Are arthropods infrared and microwave detectors? North Cent. Branch Entomol. Soc. Amer., Proc. 20:20-21.

Callahan, P.S. 1967. Insect moelcular bloelectronlcs: A theoretical and experimental study of insect sensillae as tubular waveguides, with particular emphasis on their dielectric and thermoelectret properties. Entomol. Soc. Amer. Misc. Publ. 5(7):315-347.

Callahan, P.S. 1968. A high frequency dielectrlc wavegulde on the antennae of night-flying moths (Saturnidae). Appl. Opt. $7(8)$ : $1425-1430$. 
Camin, J.H. 1950. Observations on the life history a : sensory behavior of the snake mite Ophionyssus natricis (Gervals). Ph.D. dissertation. The Ohio State University. $181 \mathrm{p}$.

Cross, H.F. 1954. Feeding tests with blood sucking mltes on heparInlzed blood. J. Econ. Entomol. $47(6): 1153-1155$,

Evans, W.G. 1964. Infrared receptors in Melanophlla acuminata DeGeer. Natur. 202:211.

Evans, W.G. 1965. The orientation of Melanophila acuminata DeGeer (Coleoptera, Buprestidae) to fires. XII Int. Congr. Entomol., Proc. p. 286.

Evans, W. G. 1966a. Morphology of the infrared sense organs of Melanophila acuminata (Buprestidae: Coleoptera). Entomol. Soc. Amer., Ann. 59(5):873-877.

Evans, W.G. 1966b. Perception of infrared radiation from forest fires by Melanophila acuminata DeGeer (Buprestidae, Coleoptera). Ecol. 47(6):1061-1065.

Farish, D.J. and R.C. Axtell. 1966. Sensory functions of the palps and first tarsi of Macrocheles muscaedomesticae (Acarina: Macrochel idae), a predator of the house fly. Entomol. Soc. Amer., Ann. $\underline{59}(1): 165-170$.

Grant, G.R.M. 1948. The sensory pits of insects considered as dielectric wave guides and resonators to intra-red rays. Roy. Soc. (Queensland), Proc. $60(8): 89-98$.

Grlffith, P.H. 1968. Investigation of insect electromagnetic communication with special reference to Hellothis zea (Boddie). Univ. Callfornia, Berkeley, Electronics Res. Lab. Rep. No. 68-3 (also USDA 12-14-100-9044(33)). $130 \mathrm{p}$.

Hackforth, H.L. 1960. Infrared radiation. McGraw-HIII Book Co., Inc., New York. 303 p.

Hodgson, E.S. 1956. Temperature sensitivity of primary chemoreceptors of insects. Anat. Rec. 125:14.

Humphrles, D.A. 1968. The host-finding behavior of the hen tlea, Ceratophyll lus gallinae (Schrank) (Siphonaptera). Parasltol. 58: 403-414.

Humphries, D.A. 1969. Behavioural aspects of the ecology of the sand martin flea Ceratophyllus styx Jordani Smit (Siphonaptera). Parasitol. 59:311-334. 
Kettlewell, H.B.D. 1961 . The radiation theory of female assembling in the Lepidoptera. Entomol. 94:59-65.

Kiely, D.G. 1953. Dlelectrlc aerials. Methuen \& Co. Ltd., London. $132 \mathrm{p}$

Knulle, W. 1967. SIgniflcance of fluctuating humldity and frequency of blood meals on the survival of spiny rat mite, Echinolaelaps echldninus (Berlese). J. Med. Entomol. $\underline{4}(3): 322-325$.

Lalthwaite, E.R. 1960. A radlation theory of the assembling of moths. Entomol. $93(1165): 113-117$ (continued to) $93(1166): 133-137$.

Machan, L. 1968. Spectral sensitivity of scorpion eyes and the possible role of shlelding plgment effect. J. Exp. Biol. 49:95-105.

McEnroe, W.D. and K. Dronka. 1966. Color vision in the adult female two-spotted spider mite. Sci. 154(3750):782-784.

Mitchell, Carl J. 1964. Population structure and dynamics of Laelaps nuttalli Hirst and L. echidninus Berlese (Acarina: Laelaptidae) on Rattas rattus and R. exulans in Hawall. J. Med. Entomol. $1(2): 151-153$.

Moncrieff, R.W. 1967. The chemical senses. Leonard Hill Books. London. $760 \mathrm{p}$.

Okress, E.C. 1965. Dielectric and organic superconducting waveguide, resonator, and antenna models of insects' sensory organs. App I. Opt. $4(10): 1350-1351$.

Owen, B.L. 1956. Life history of the spiny rat mite under artificial conditions. J. Econ. Entomol . 49(5):702-703.

Patel, C.K.N. 1968. High-power carbon dioxide lasers. Scl. Amer. $\underline{219}(2): 22-33$.

Perkin-Elmer Corporation. 1952. Introduction to infrared spectrometry. Vol. I. Perkin-Elmer Corporation. Norwalk, Connecticut. 22 p.

Peterson, D.G. and A.W.A. Brown, 1951. Studies of the responses of the female Aedes mosquito 111 . The response of Aedes aegyotl (L.) to a warm body and its radiation. Entomol. Res. Bull. 42(8):535541 .

Pike, C.A. 1967. Lasers and masers. The Bobbs-Merrlll Co., Inc. New York. 176 p. 
Reynolds, D.L. 1949. The behavior of the common rat mite Echinolaelaps echidninus (Berlese). M.S. Thesis. Ohlo State University. 30 p.

slifer, E.H. 1968. The thin-walled olfactory sense organs on insect antennae, p. 233-245. In J.W.L. Beament and J.E. Treherne (ed.), Insects and physlology. American Elsevier Publishing Company, Inc. New York.

Strandtmann, R.W. and G.W. Wharton. 1958. Manual of mesostigmatid mites parasitic on vertebrates. Inst. Acarology. Unlv. Maryland. Contrib. 4. $69 \mathrm{p}$.

Yasko, A. 1963. Infra-red radiation. Rev. ed. 1968. The Chemical Rubber Co., Cleveland, Ohio. $445 \mathrm{p}$.

Vercammen-Grandjean, P.H. 1965. On the true nature of the "striate" solenidion in chiggers (Trombiculidae: Acarina). Acarologia $\underline{7}(2): 318-320$.

Warren, J.W. and U. Proske. 1969. Infrared receptors in the facial pits of the Australian python Morelia spllotes. Scl. 159: 439-441.

Wharton, G.W. and H.F. Cross. 1957. Studies on the feeding habits of three species of laelaptid mites. J. Parasitol. 43(1):45-50.

Wharton, G.W. and K. Kanungo. 1962. Some effects of temperature and relative humidity on water-balance in females of the spiny rat mite, Echinolaelaps echidninus (Acarina: Laelaptidae). Entomol. Soc. Amer., Ann. 55 (5):483-492.

Wharton, G.W., W. Parrish, and D.E. Johnston. 1968. Observations on the fine structure of the cuticle of the spiny rat mite, Laelaps echidnina (Acari-Mesostigmata). Acarologla 10(2):206-214.

Wright, R.H. 1963. Molecular vibration and insect sex attractants. Natur. 198(4879): 455-459.

Zolotarev, E. Kh. and Yu. A. Ellizarov. 1963. Studies of chemoreception in insects and ticks. Location of the chemoreceptors in the tick Ixodes persulcatus P. Sch. Translated from Russlan Vestnik Moskovskogo Universiteta, Ser. 6, Blologlya, Pochvevedenle $18(1): 7-9$. 